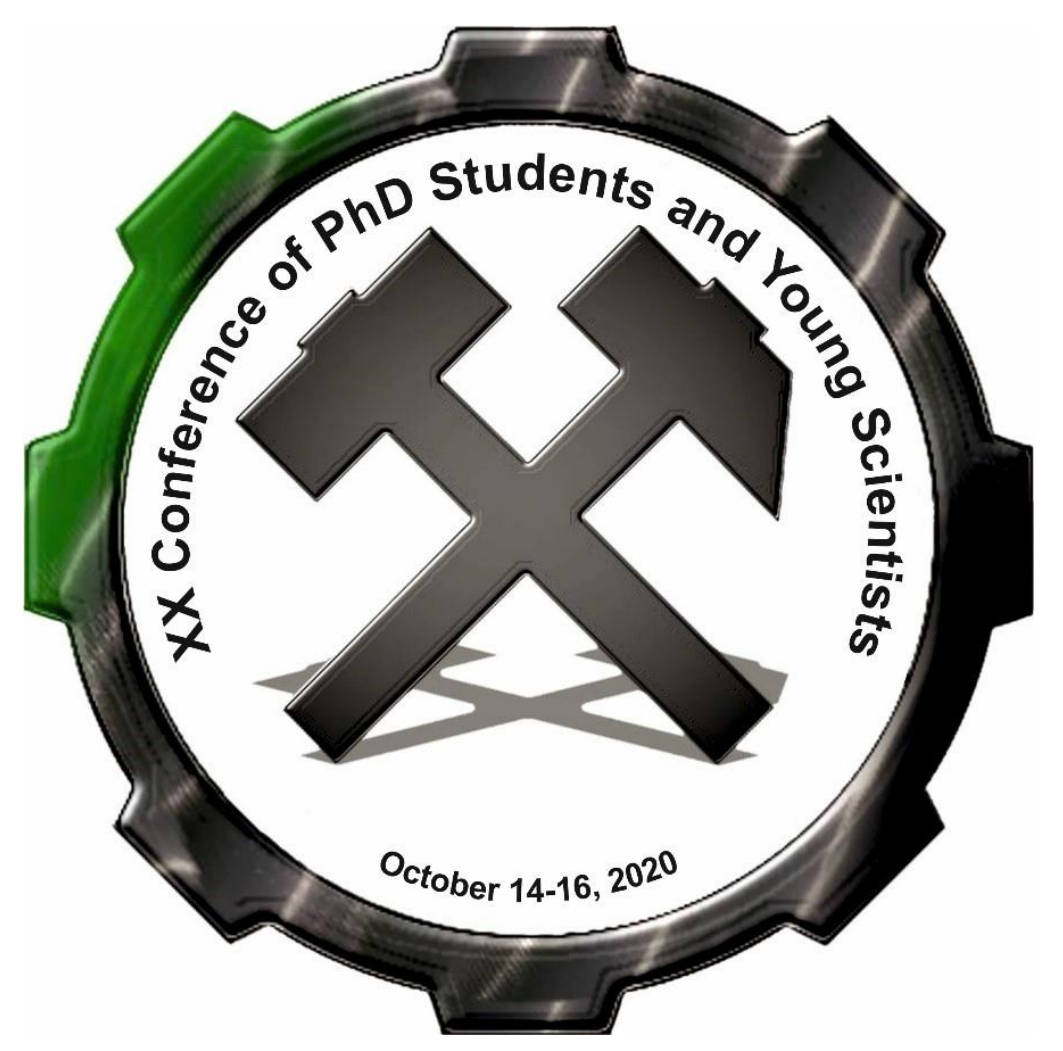

Conference of PhD Students and Young Scientists 


\section{Book of abstracts}

\section{Conference of PhD Students and Young Scientists}

Interdisciplinary topics in mining and geology 
Publication of Book of abstracts was co-financed by

Związek Pracodawców Porozumienie Producentów Węgla Brunatnego

Poltegor-Instytut. Instytut Górnictwa Odkrywkowego

Politechnika Wrocławska

Printed based on submitted abstracts.

\section{Technical editors}

Natalia Suchorab, Damian Kasza, Jarosław Wajs

\section{Publisher}

Oficyna Wydawnicza Politechniki Wrocławskiej

\section{ISBN}

978-83-7493-161-8

DOI

https://doi.org/10.37190/XXCPSYS 


\section{Spis treści}

\section{ANALYSIS OF HISTORICAL CHANGES IN THE LIMIT VALUE OF NITROGEN OXIDES CONCENTRATIONS FOR UNDERGROUND MINING}

A. Banasiewicz

POTENTIAL RESOURCES ON 6 HEBE ASTEROID

K. Blutstein 9

ANALYSIS OF THE VEGETATION CONDITION ON THE AREA OF THE CLOSED BABINA MINE IN 1989-2019 USING MULTISPECTRAL SATELLITE IMAGES

A. Buczyńska, J. Blachowski 10

REMOTE SENSING MONITORING OF INFLUENCE OF UNDERGROUND MINING IN THE AREA OF THE S3 EXPRESS ROAD

N. Bugajska, W. Milczarek 11

METHOD FOR DETERMINING THE TRACTION FORCE OF THE GROUND CABLE CAR DRIVE

D. V. Chezganova, I. V. Muradov, A. V. Zhaglovskaya. 12

INFLUENCE OF GREEN AREAS ON AIR TEMPERATURE

M. Chojwa. 14

MAGNETIC MINERALS DISSEMINATION EXPRESS CONTROL METHOD

A. Chumakov, V. Prischepov, K. Melekhina, A. Ivannikov 15

TRANSFER STATION DESIGN OPTIMIZATION WITH THE USE OF REVERSE ENGINEERING TECHNIQUES AND DEM SIMULATIONS

B. Doroszuk, J. Wajs 17

ANALYSIS OF AMMONIUM AND PHOSPHATES CONCENTRATION TIME SERIES IN RIVER WATER

I. Yu. Drozdov, A. V. Aleksakhin, Yu. V. Aleksakhina, D. A. Petrusevich 18 MATHEMATICAL MODELS OF WATER POLLUTION EVALUATION

I. Yu. Drozdov, A. V. Aleksakhin, Yu. V. Aleksakhina, D. A. Petrusevich 20 METHOD FOR DETERMINING THE LOADS ON THE DEFLECTION MODULE OF THE PUSH-THE-BIT ROTARY STEERABLE SYSTEM

A. Epikhin, V. Zhironkin, D. Szurgacz, K. Trzop. 22

EMPIRICAL FORMULATIONS FOR THE ESTIMATION OF DEFORMABILITY PARAMETERS OF ROCK MASSES BY MEANS OF DYNAMIC TESTING

N. Esteban, R. A. Galindo. 
NEW METHODOLOGY OF SIMPLIFIED ROCK TESTS TO DETERMINE BEARING CAPACITY IN EMBANKMENTS AND EXCAVATION BOTTOMS

C. L. Garrido, I. Morilla, R. A. Galindo 24

IMPACT OF TRANSIENT LUMINOUS EVENTS ON THE CHEMISTRY OF ATMOSPHERE AS A SPECIAL CASE OF THE IMPACT OF THUNDERSTORMS

P. Jujeczko 26

A REVIEW OF THE GEOCHEMICAL CHARACTERISTICS OF THE NIEMSTÓWWIELOWIEŚ AREA AND ITS EXPLORATION SIGNIFICANCE, LOWER SILESIA, POLAND

W. Kaczan, H. Wirth. 28

DEVELOPMENT OF EXTRATERRESTRIAL RESOURCES' EXTRACTION PREREQUISITES FOR THE FORMATION OF A NEW SCIENTIFIC DISCIPLINE

A. M. Khairutdinov, Y. Tyulyaeva, Ch. Kongar-Syuryun, A. Rybak. 30

MOVING TOWARDS SUSTAINABLE MINING THROUGH SPARING GEOTECHNOLOGY

A. Khairutdinov, A. Ubysz, A. Adigamov 32

STOPE STABILITY ASSESSMENT BY THE MATHEWS-POTVIN METHOD: A CASESTUDY OF OPEN STOPING IN SALT ROCK MASS UNDER CONDITIONS OF SECONDARY STRESS FIELD

Ch. V. Khazhyylai, M. A. Kosyreva, V. A. Eremenko, A. R. Umarov. 34

MODELS AND ALGORITHMS OF CHOICE OF DEVELOPMENT TECHNOLOGY OF DEPOSITS WHEN SELECTING THE COMPOSITION OF THE BACKFILLING MIXTURE

Ch. Kongar-Syuryun, A. Ubysz, V. Faradzhov 35

AREAS OF NATURAL CONFLICTS IN HARMONIZED THEMATIC MAPS OF THE STRZELIN COUNTY

P. Kozińska, A. Górecki 38

IDENTIFICATION OF AREAS AT RISK OF HYDROGEOLOGICAL DROUGHT IN THE BIALA LĄDECKA RIVER BASIN (SUDETES MOUNTAINS, POLAND)

A. Kozłowska. 39

A RATIONAL APPROACH TO THE MANAGEMENT OF UNDERGROUND MINING IN COMPLEX HYDROGEOLOGICAL AND GEOMECHANICAL CONDITIONS BASED ON A RISK ASSESSMENT

E. Krasyukova, I. Aynbinder, A. Ivannikov 40 
COMPARISON OF 3D MODELS OF AN OBJECT PLACED IN TWO DIFFERENT MEDIA (AIR AND WATER) CREATED ON THE BASIS OF PHOTOS OBTAINED WITH A MOBILE PHONE CAMERA

P. Kujawa 42

MESOSCALE CONVECTIVE SYSTEM AS A SOURCE OF ELECTROMAGNETIC SIGNALS REGISTERED BY GROUD-BASED SYSTEM AND DEMETER SATELLITE

K. Martyński, J. Błęcki 43

UTILIZATION OF FIELD SEISMOMETERS FOR MEASURING THE PARASEISMIC VIBRATIONS OF MINING BLASTS

O. Molinek, M. Vokurka, A. Mokrosova, J. Kotrbanec 44

STATISTICAL ANALYSIS OF SURFACE DEFORMATIONS CAUSED BY SEISMICITY INDUCED BY UNDERGROUND MINING

K. Owczarz, J. Blachowski 45

METHODOLOGY FOR CALCULATE BEARING CAPACITY OF SOFT SOILS UNDER CYCLIC LOADING

D. R. Panique Lazcano, R. A. Galindo Aires, C. Olalla Marañon 46

USE OF ABCD-MATRIX METHOD FOR THE SIMULATION OF LASER-ULTRASONIC PROBING PULSE PROPAGATION A IN A LAYERED MEDIUM OF THE OPTICALACOUSTIC TRANSDUCER

A. I. Pashkin..... 48

APPLICATION OF HIGH- AND LOW-PASS SPATIAL FILTERS IN ANALYSIS OF CONE PENETRATION TEST (CPTU)

J. Rainer, I. Bagińska 50

THE USE OF MAN-MADE WASTE, THE VECTOR OF GREEN GEOTECHNOLOGY DEVELOPMENT

A.Sharova, V. Faradzhov, M. Khayrutdinov, A. Kopylov 52

EPIGENETIC AND INDUCED FRACTURES FROM THE RADKÓW BLUFF (STOŁOWE MOUNTAINS) DOCUMENTED WITH TERRESTRIAL LASER SCANNER STRUCTURAL IMPLICATIONS

D. Sokalski, J. Wojewoda, A. Kowalski 55

PRELIMINARY RESEARCH TO DETERMINE THE THERMAL CONDITION OF THE BELT CONVEYOR'S DRIVE UNIT IN AN UNDERGROUND HARD COAL MINE 
SPECIFIC ENERGY CONSUMPTION OF BELT CONVEYORS - K-MEANS CLUSTERING

N. Suchorab, R. Król 58

FAILURE ANALYSIS OF ELEMENTS OF STORAGE BUNKERS USED IN KGHM RUDNA COPPER MINE

M. Szczerbakowicz, N. Suchorab, R. Król 59

ASSESSMENT OF HUMAN IMPACT ON RIVERS AND GROUNDWATER QUALITY WITH THE USE OF ANTIBIOTIC RESIDUES ANALYSIS

K. Ślósarczyk 60

DEVELOPMENT OF A BUILDING TOPOLOGICAL MODEL FOR INDOOR NAVIGATION

P. Trybała, A. Gattner 62

PREVENTIVE MEASURES TO MINIMIZE NATURAL HAZARDS IN THE POLISH UNDERGROUND MINING INDUSTRY

K. Trzop, D. Palka, D. Szurgacz, L. Sobik. 63

UNDERGROUND HARD-COAL MINE AS A HOSTING FACILITY FOR A DATA PROCESSING CENTER INFRASTRUCTURE

K. Varnavskiy, F. Nepsha, R. Kostomarov, Q. Chen 65

LIQUIDATION OF THE EXPLORATION PIT N. 11 FROM THE ROZNA URANIUM DEPOSIT

M. Vokurka, O. Molinek.

PROCEDURE FOR LAB-SCALE STRENGTH AND FAILURE TESTING OF PHYSICAL MODELS OF FRAME MINE STRUCTURES

N. G. Vysotin, V. I. Leizer, V. A. Eremenko, A. M. Yanbekov 68

DEVELOPMENT OF LOW-COST UNMANNED SURFACE VEHICLE SYSTEM FOR BATHYMETRIC MEASUREMENTS

J. Wajs, D. Kasza, B. Skrabanek.

MEASURES TO REDUCE THE ENVIRONMENTAL IMPACT OF THE ŻELAZNY MOST TAILINGS STORAGE FACILITY

S. Zieliński, P. Stefanek 71

TORSIONAL VIBRATIONS MEASUREMENT TOOLS IN CONDITION MONITORING AND DIAGNOSTICS OF MINING MACHINES

B. Ziętek, P. Krot, P. Borkowski 72 


\title{
ANALYSIS OF HISTORICAL CHANGES IN THE LIMIT VALUE OF NITROGEN OXIDES CONCENTRATIONS FOR UNDERGROUND MINING
}

\author{
A. Banasiewicz ${ }^{1 *}$ \\ ${ }^{I}$ Faculty of Geoengineering, Mining and Geology, Wroclaw University of Science and \\ Technology, Na Grobli 15, 50-421 Wroclaw, Poland
}

Keywords: ventilation, deep underground mine, NOx gases, gas hazards

Providing adequate ventilation in underground mines is a growing problem. The constantly increasing depth of exploitation is a challenge for ventilation services. However, not only the depth of exploitation, but also the increasing knowledge of the impact of noxious factors on the health of employees contributes to the constant changes in the values of permissible concentrations of gases to improve working conditions. One of the main hazards to which the restrictions are introduced is the gas hazard. Nitrogen oxides are one of the most important gas compounds that occur in underground mining plants. The article will present the beginnings of recognizing hazardous gases as harmful and the history of limiting the concentrations of these compounds in underground mines. The restrictions concern compounds from the NOx family, such as nitrogen oxide (NO) and nitrogen dioxide $\left(\mathrm{NO}_{2}\right)$. The concentration limits in force in Poland refers to both European directives and regulation acts issued in our country. The subject of nitrogen oxides in the world has recently been very important, and in Poland, it mainly concerns copper and salt mines. Although research has not yet been officially carried out to identify the sources of nitrogen oxide emissions in mines, it is recognized that most of these compounds come from exhaust gases produced by self-propelled mining machinery with diesel engines. It is presumed that nitrogen oxides enter the mine atmosphere also through a blasting and from the natural outflow of these gases from the rock mass. The presence of nitrogen oxides in the mine atmosphere in Polish copper ore mines is related, among others, to the mineral o the mineral mining Analysis of historical changes in the limit value of nitrogen oxides concentrations for underground mining cycle.

\footnotetext{
*Corresponding author: Aleksandra.Banasiewicz@pwr.edu.pl
} 


\author{
Book of abstracts \\ XX Conference of PhD Students and Young Scientists \\ October 14-16, 2020
}

\title{
POTENTIAL RESOURCES ON 6 HEBE ASTEROID
}

\author{
K. Blutstein ${ }^{1 *}$ \\ ${ }^{1}$ Wroctaw University of Science and Technology, Faculty of Geoengineering, Mining and \\ Geology; Wybrzeże S. Wyspiańskiego 27; 50-370 Wrocław
}

Keywords: meteorite, $\mathrm{H}$ chondrite, ordinary chondrite, $6 \mathrm{Hebe}$, extraterrestrial resources

6 Hebe located in the main asteroid belt is one of the potential extraterrestrial objects of future mining exploitation. It is also widely recognized as the parent body of $\mathrm{H}$ chondrites (Gaffey et al., 1993). Based on the chemical analyses of $\mathrm{H}$ chondrites, the average chemical composition of the asteroid was determined. This asteroid is composed of, among others, [in $\mathrm{Mg}$ ]: $\mathrm{Fe}\left(3.54 \cdot 10^{15}\right), \mathrm{Ni}\left(2.17 \cdot 10^{14}\right), \mathrm{Cr}\left(4.44 \cdot 10^{13}\right), \mathrm{Co}\left(1.05 \cdot 10^{13}\right), \mathrm{Cu}\left(1.19 \cdot 10^{12}\right)$, Mo $\left(1.78 \cdot 10^{10}\right)$. These elements are a component of various minerals, including minerals that can be a future object of exploitation. Primarily, they are FeNi alloy minerals, but also e.g. chromite. The reserves of these elements are smaller, but assuming that it is 10 or even $1 \%$ of resources, they are still huge. The reserves of 6 Hebe can cover Earth's demand for selected elements for several thousand to even several million years. For comparison, with the current mining production of iron, the earth's resources will last 153 years, and reserves - 56 years (USGS, 2019). Extraterrestrial mining may in the future be an ecological alternative to mining on Earth.

\section{REFERENCES}

Gaffey M., Bell J., Brown H., Burbine T., Piatek J., Reed K., Chaky D., 1993, Mineralogical Variations within the S-Type Asteroid Class, Icarus, 106, 2, s. 573-602

U.S. Geological Survey, 2019, Mineral commodity summaries 2019, U.S. Geological Survey, Reston, Virginia

\footnotetext{
* Corresponding author: konrad.blutstein@pwr.edu.pl
} 


\title{
ANALYSIS OF THE VEGETATION CONDITION ON THE AREA OF THE CLOSED BABINA MINE IN 1989-2019 USING MULTISPECTRAL SATELLITE IMAGES
}

\author{
A. Buczyńska ${ }^{1 *}$, J. Blachowski ${ }^{1}$ \\ ${ }^{I}$ Faculty of Geoengineering, Mining and Geology, Wroctaw University of Science and \\ Technology, 15 Na Grobli street, 50-421 Wroctaw, Poland
}

Keywords: vegetation indices, post-mining area, Babina mine, Landsat program, plant cover condition

Technical and biological treatments, aiming at granting or restoring use/natural values of lands degraded by mining operations, are carried out already at the stage of mining works and continue after the end of exploitation. As a result of these activities, area of plant cover increases and condition of vegetation in the former mineral extraction is improved. However, monitoring of post-mining areas in various regions of the world indicates that in the sites of former exploitation local degradation of vegetation may occur, despite the completion of the reclamation process. Adverse changes in flora can be caused for example by water penetrating deep into the ground through the system of underground pavements or their collapsing. The purpose of this publication is to present the changes in the condition of plant cover within the Pustków mining field, one of the four fields of the closed lignite "Friendship of Nations - Babina Shaft" mine. The analysis of variation in the state of the plant cover health was carried out for the period of 1989-2019 based on NDVI, EVI and GNDVI spectral indices, developed using multispectral images of the Landsat TM/ETM+/OLI missions. The obtained results provide information about systematic improvement of the flora condition in the analysed region and indicate an increase in green areas. In 1989-2019, overgrowing of the shorelines of anthropogenic lakes and heaps was observed, as well as reservoir with a decreasing surface area due to vegetation succession was identified. In 2016, local degradation of the plant cover was also observed in the northwestern part of the Pustków field. The obtained results prove the necessity of continuous monitoring of the flora health in the area of the analysed mine, but also in other post-mining areas.

\footnotetext{
*Corresponding author: anna.buczynska@pwr.edu.pl
} 
October 14-16, 2020

\title{
REMOTE SENSING MONITORING OF INFLUENCE OF UNDERGROUND MINING IN THE AREA OF THE S3 EXPRESS ROAD
}

\author{
N. Bugajska ${ }^{1 *}$, W. Milczarek ${ }^{1}$ \\ ${ }^{1}$ Wroclaw University of Science and Technology, Wybrzeże Wyspiańskiego 27 \\ 50-370 Wroctaw, Poland
}

Keywords: highway subsidence, PSInSAR, Copernicus Sentinel-1, StaMPS, S3 Express Road

Land subsidence is strongly associated with the activities of underground mines. Direct influence of exploitation lead to the formation of subsidence troughs, which are a common phenomenon in the Legnica-Glogow Copper Belt, in southwest Poland, where copper ore is currently intensively mined. As a result, the process of creating troughs may cause significant deformations in the surrounding urban infrastructure, including highways, bridges and railways. Satellite radar interferometry (InSAR), as a remote sensing method, appears to be a useful tool for detecting this type of extensive terrain surface change (Delgado Blasco et al., 2019).

Aim of this research was to detect the occurrence of displacements of the S3 Express Road section between the Glogow West Node and the Glogow South Node. For this purpose 29 images provided by European Space Agency (ESA) over descending orbit 22 was obtained from the Sentinel-1A satellite for the period from May 5, 2019 to April 26, 2020. Open source softwares has been used - GMTSAR (Sandwell et al., 2011) to generate differential interferograms using the Persistent Scatterer Interferometry (PSI) method and Stanford Method for Persistent Scatterers (StaMPS) (Hooper et al., 2008) to process Persistent Scatters (PS). The express road, as an anthropogenic object, is characterized by relatively high radar backscatter, thanks to which subsidence of the area are clearly noticeable and indicate the trend of long-term deformations.

\section{REFERENCES}

Delgado Blasco J.M., Foumelis M., Stewart C., Hooper A., 2019. Measuring Urban Subsidence in the Rome Metropolitan Area (Italy) with Sentinel-1 SNAP-StaMPS Persistent Scatterer Interferometry. Remote Sens. $11,129$.

Hooper A., Bekaert D., Spaans K., Arikan M., 2012. Recent advances in SAR interferometry time series analysis for measuring crustal deformation, Tectonophysics, 514-517, pp.1-13. doi:10.1016/j.tecto.2011.10.013

Sandwell D., Mellors R., Tong X., Wei M., Wessel P., 2011. GMTSAR: An InSAR Processing System Based on Generic Mapping Tools. UC San Diego: Scripps Institution of Oceanography. Retrieved from: http://escholarship.org/uc/item/8zq2c02m

\footnotetext{
*Corresponding author: natalia.bugajska@pwr.edu.pl
} 


\title{
METHOD FOR DETERMINING THE TRACTION FORCE OF THE GROUND CABLE CAR DRIVE
}

\author{
D. V. Chezganova ${ }^{1}$, I. V. Muradov ${ }^{1 *}$, A. V. Zhaglovskaya ${ }^{1}$ \\ ${ }^{1}$ National University of Science and Technology MISIS, Leninsky Av. 4, 119991, Moscow, \\ Russia
}

Keywords: ground cable car, traction force, transmission efficiency

Ground-based cable cars are widely used in coal mines. For the transport of auxiliary goods and people on site mining operations with a variable profile of rails exceeding $\pm 5^{\circ}$, which excludes the use of locomotive rollback and the possibility of using a terminal cable car, ground cable cars are used. They are used mainly on ventilation horizons in workings with stable soils. When transporting goods in long curved workings with unpredictable impact of negative factors, the vehicles used practically work in conditions of uncertainty. As a result, numerous accidents and failures in the auxiliary transport system serving the preparatory faces.

The article is devoted to the problem of determining the necessary indicators of the traction force of the ground cable car drive, in the modes of start - up, steady motion and braking when operating them in curved workings with a variable path profile. Therefore, for each case of using a cable car in the mine, the required amount of traction must be calculated based on the specific values of the cable car profile parameters and the curvature of the path in the horizontal plane. The method of determining the traction force given below allows you to calculate the required traction force based on the design data of the ground cable car for specific operating conditions. To calculate the traction force, all the resistances to the movement of the composition of the trolleys and the traction rope are determined.

Due to failures in the operation of local transport means, preparatory mine faces lose up to $0.53 \mathrm{~m}$ of workings per shift. In this regard, the purpose of this method is to establish the actual indicators of the traction force of the ground cable car drive, in the modes of startup, steady motion and braking when operating them in curved workings with a variable path profile. The first paragraph after a heading is not indented.

The mode of operation during acceleration and deceleration of the transport system is more dangerous in terms of slippage than at a steady speed, therefore, the condition of no slip in unsteady modes is always checked. This selects the acceleration and deceleration values.

The traction drive is driven by a traction wheel. A steel cable is suspended from a traction wheel. The method of winding the traction rope mainly depends on the position of the traction device, the rated load and the rated speed. When selecting and determining the cable winding mode, high transmission efficiency, reasonable power consumption, and long

*Corresponding author: miv-29@mail.ru 


\section{Book of abstracts \\ $\mathrm{XX}$ Conference of PhD Students and Young Scientists \\ October 14-16, 2020}

service life should be taken into account. For this purpose, the calculated parameters of the tractive effort are used.

The maximum effective pulling force that can be generated in a tow wheel groove is the coefficient of friction between the steel rope and the wheel groove and the function of the steel rope around the corner of the tow wheel. Measures to increase traction capacity are:

- to change the shape of the rope groove and the material of the rope groove to improve the coefficient of friction,

- $\quad$ to increase the angle of the envelope.

\section{REFERENCES}

Sidorova E Y, Kostyukhin Y and Shtanskiy V 2019 Creation of Conditions for the Development of Production of Science-Intensive Products Based on the Potential of Russian Applied Scientific Organizations. Smart Innovation, Systems and Technologies 139 584-591.

Sidorova E 2019 The main factors and conditions determining the feasibility of production of high-tech products based on the potential of applied research organizations. International Multidisciplinary Scientific GeoConference Surveying Geology and Mining Ecology Management, SGEM 19(5.3) 841-847

Yurievich A A, Kostyukhin Y Y, Skryabin O O, Androsova I V and Zhaglovskaya A V 2017 National innovation system as a model of economic development. International journal of advanced biotechnology and research $32075-2082$.

Sidorova E 2019 Modern strategic decisions in the field of waste as a basis of development of circular economy and greening of industrial production. International Multidisciplinary Scientific GeoConference Surveying Geology and Mining Ecology Management, SGEM 19(5.3) 531-538

Vikhrova N 2018 Implementation of the resource saving concept by involving in the recycling of the titanium sheet at the metallurgical front. International Multidisciplinary Scientific GeoConference Surveying Geology and Mining Ecology Management, SGEM 18(5.3) 477-484

Kostygova L A, Sidorova E Yu and Vikhrova N O 2019 Modern clusters and assessment of their innovative development. Entrepreneurship and Sustainability Issues 7(1) 603-614

Kostyukhin Y 2019 Conceptual provisions of sustainable development of socio-economic systems (on the example of an industrial enterprise). International Multidisciplinary Scientific GeoConference Surveying Geology and Mining Ecology Management, SGEM 19(5.3) 131-138

Kostyukhin Y 2016 Enhancement of labor efficiency in coal mining industry. Gornyi Zhurnal (10) 41-44

Sidorova E and Muradov I 2018 Formation of an effective corporate governance system for industrial enterprises. International Multidisciplinary Scientific GeoConference Surveying Geology and Mining Ecology Management, SGEM 18(5.3) 407-414 


\author{
Book of abstracts \\ $\mathrm{XX}$ Conference of PhD Students and Young Scientists \\ October 14-16, 2020
}

\title{
INFLUENCE OF GREEN AREAS ON AIR TEMPERATURE
}

\author{
M. Chojwa ${ }^{1 *}$ \\ ${ }^{1}$ Department of Geodesy and Geoinformatics, Faculty of Geoengineering, Mining and \\ Geology, Wroctaw University of Science and Technology
}

Keywords: LST, Land surface temperature, green areas, heat island, remote sensing

Currently, the phenomenon of global warming is observed. Since the end of the 19th century, the average temperature on Earth has increased by $0.9^{\circ} \mathrm{C}$, which is caused by the increase in greenhouse gases emissions to the atmosphere. It is important to monitor the emerging climate change with rapid economic development. The cooling effect of urban green areas on cities is known. However, the cooling effect of these sites has spatial, temporal and plant specific properties.

The purpose of this research is to determine the impact of post-mining and reclaimed areas on the prevailing air temperature and to determine the extent of the impact of these sites as well as to determine the distribution of pollutants. This paper presents an overview of the methods used to determine the impact of green areas on air temperature and an attempt to indicate which method can be used in mining areas.

\section{REFERENCES}

P. Yang, Z. Xiao, M. Ye, 2016, Cooling effect of urban parks and their relationship with urban heat islands, Atmospheric and Oceanic Science Letters, 9:4, 298-305, DOI: 10.1080/16742834.2016.1191316

M. Faroughi, M. Karimimoshaver, F. Aram, E. Solgi, A. Mosavi, N. Nabipour, K. Chau, 2020, Computational modeling of land Surface temperature using remote sensing data to investigate the spatial arrangement of buildings and energy consumption relationship, Engineering Applications of Computational Fluid Mechanics, 14:1, 254-270, DOI: 10.1080/19942060.2019.1707711

M. Simwanda, M. Ranagalage, R. C. Estoque, Y. Murayama, 2019, Spatial Analysis of Surface Urban Heat Islands in Four Rapidly Growing African Cities

Y. Wang, Y Zhang, N. Ding, K. Qin, X. Yang, 2020, Simulating the Impact of Urban Surface Evapotranspiration on the Urban Heat Island Effect Using the Modified RS-PM Model: A Case Study of Xuzhou, China

\footnotetext{
* Corresponding author: monika.chojwa@pwr.edu.pl
} 


\title{
MAGNETIC MINERALS DISSEMINATION EXPRESS CONTROL METHOD
}

\author{
A. Chumakov ${ }^{1}$, V. Prischepov ${ }^{1}$, K. Melekhina ${ }^{1}$, A. Ivannikov ${ }^{1 *}$ \\ ${ }^{1}$ National University of Science and Technology MISIS, Leninsky Av. 4, 119991, \\ Moscow, Russia
}

Keywords: dissemination, magnetite, magnetic properties, ore preparation, coercive force, technological properties of ores

Today, one of the most important problems in the field of mineral processing is the unstable behavior of the technological properties of ore material entering the processing plant. The main technological properties that have a direct impact on the processing of mineral raw materials (crushing, grinding, etc.) are the mineral composition of the ores, the chemical composition of the ores, the texture and structural features of the ores, and the physical and mechanical properties of the ores. The physical and mechanical properties of ores do not undergo significant changes within a single deposit, which makes the methods for studying these properties quite universal. Acoustic emission methods for studying the physical and mechanical properties of ores can be used to study ferruginous quartzites (Voznesenskii et al., 2005, Voznesenskii et al., 2006).

This problem is solved by controlling the quality of the ore charge, stabilizing the properties of raw materials. The main criterion is the material composition of the source ore material. At the same time, such a parameter as dissemination of a productive mineral is not taken into account. This leads to the fact that the grinding complex with pre-set operating parameters for certain technological properties of the mixture will work less efficiently, the degree of under-grinding and over-grinding of grains of bearing minerals will increase. The difficulty in taking into account the grain size of useful minerals is quite sharp changes in dissemination even within the limits of one ore body under development. An analysis of the magnetic properties of ferruginous quartzites of the Kursk magnetic anomaly shows the presence of prerequisites for the integration of express methods for controlling dissemination of magnetite in process control systems of concentration plants. The relationship between the coercive force of the ore material and the size of the magnetite particles that make up the ore is experimentally established. This creates the basis for determining the size of magnetite grains in the incoming ore.

To construct a graph of the magnetic hysteresis loop and determine the values of the magnetic properties, a laboratory hardware complex of the Ferrograph type was used. The test material was 120 gram samples of ferruginous quartzite from the Kursk Magnetic Anomaly (KMA) deposits: after crushing in a crushing and screening complex in the amount of twenty pieces; drill cuttings in the amount of twenty pieces. For measurements,

* Corresponding author: ivannickov@bk.ru 


\section{Book of abstracts \\ $\mathrm{XX}$ Conference of PhD Students and Young Scientists \\ October 14-16, 2020}

the samples were divided into three samples of $40 \mathrm{~g}$. Each sample was placed inside the hardware complex, in an external magnetic field with gradually increasing intensity. At the same time, the values of the magnetic field induction in the test sample were recorded. Based on these data, a magnetic hysteresis loop was plotted and its parameters were determined, such as: coercive force, saturation magnetization, remanent magnetization, saturation field strength.

Previously, during the optical-mineralogical analysis, the dissemination of magnetite in the samples of ferruginous quartzite was determined. By means of a regression analysis, a relationship was established linking the parameters of the magnetic properties with the size of the inclusions of the magnetic mineral, type.

Moreover, a feature is the fact that it is possible to install this complex in an ore stream with a continuous supply of material for analysis. It is worth noting that for the ore material that was studied in this work, the relative error in determining the impregnation of magnetite was $4.53 \%$ for ore after crushing and $3.03 \%$ for drill cuttings. This control method will improve the efficiency of the ore preparation process control by obtaining operational information on dissemination. Thus, the described complex can be considered a qualitative express method for controlling the dissemination of magnetite in ferruginous quartzites.

\section{REFERENCES}

Voznesenskii A. S., Ertuganova E. A., Vil'yamov S. V. and Tavostin M. N. 2006 Studying themechanism of acoustic emission in failure of rock salt by dissolving. J Min Sci. 42(1) 35-42, https://doi.org/10.1007/s10913-006-0027-6

Voznesenskii A. S. and Tavostin M. N. 2005. Acoustic Emission of Coal in the Postlimiting Deformation State. J Min Sci. 41(4) 291-297. https://doi.org/10.1007/s10913-005-0094-0 


\title{
TRANSFER STATION DESIGN OPTIMIZATION WITH THE USE OF REVERSE ENGINEERING TECHNIQUES AND DEM SIMULATIONS
}

\author{
B. Doroszuk ${ }^{1 *}$, J. Wajs ${ }^{1}$ \\ ${ }^{1}$ Wroctaw University of Science and Technology, Wybrzeże Stanisława Wyspiańskiego 27, \\ 50-370 Wroctaw, Poland
}

Keywords: Reverse Engineering, Discrete Element Method, Simulations, Transfer Chute

Optimization of the old mining equipment without documentation requires model preparation based on the performed measurements. Measurements may be taken with the use of 3D scanning techniques. An obtained point cloud can be used to prepare a 3D model of the scanned equipment so that the model can be used as a starting point for the future optimization process.

In this work author will describe the optimization of the transfer station from the polish granite mine "Graniczna". Transfer station connects two conveyor belts, and bad design can harm the continuity of the bulk material transportation (Doroszuk \& Król, 2019). In this specific transfer point, blockage of the station was observed while the momentary performance of the feeding conveyor exceeds the typical performance.

Improvement of the transfer point design can be performed with the use of the Discrete Element Method (DEM). DEM is the method that allows simulating the behavior of the bulk material. It simulates multiple separate particles that can represent transported rocks (Walker et al., 2020).

In this work, the simulations of the material flow through the transfer point with the current and new proposed designs were performed. Simulations were performed with the high performance of the feeding conveyor to test if the new transfer point does not block like the existing one. After the analysis of the tested variants, the one with the lowest risk of the potential blockage was selected.

\section{REFERENCES}

Doroszuk, B., Król, R., 2019. Analysis of conveyor belt wear caused by material acceleration in transfer stations. Mining Science, Vol. 26, 189-201.

Walker, P., Doroszuk, B., Król, R., 2020. Analysis of ore flow through longitudinal belt conveyor transfer point. Eksploatacja i Niezawodnosc - Maintenance and Reliability. Vol. 22, No. 3, 536-543.

\footnotetext{
*Corresponding author: blazej.doroszuk@pwr.edu.pl
} 


\title{
ANALYSIS OF AMMONIUM AND PHOSPHATES CONCENTRATION TIME SERIES IN RIVER WATER
}

\author{
I. Yu. Drozdov ${ }^{1 *}$, A. V. Aleksakhin ${ }^{2}$, Yu. V. Aleksakhina ${ }^{3}$, D. A. Petrusevich ${ }^{1}$ \\ ${ }^{1}$ Russian Technological University (MIREA), Moscow, 119454, Prospekt Vernadskogo, \\ 78, Russia \\ ${ }^{2}$ National University of Science and Technology "MISIS", Moscow, 119049, Leninsky \\ Prospekt, 4, Russia \\ ${ }^{3}$ Moscow Polytechnic University, Moscow, 107023, Bol'shaya Semenovskaya, 38, Russia
}

Keywords: Time Series Analysis, ARIMA, ARDL, Water Pollution

We present an application of certain time series analysis methods to investigate river water pollution in Ukraine. We are using datasets provided by the Ukrainian Government (State Water Resources Agency of Ukraine) containing information about concentrations of ammonium ions (Mokin, 2020a) and phosphate ions (Mokin, 2020b) sampled at seven consequent water monitoring stations. Due to the amount of available observations we restrict our analysis to target station and stations 1 and 2, as other stations have more missing values than actual data, thus providing little useful information.

We have fitted ARIMA models to ammonium and phosphate time series at target stations using two different approaches: one using automatic forecasting technique proposed by Hyndman (Hyndman and Khandakar, 2008) (based on information criterion minimization) and the other being Box-Jenkins methodology (Box and Jenkins, 2008) (based of ACF and PACF analysis). Model fitting results are provided in tables 1 and 2. Residual analysis confirms that constructed models are able to describe essential dependencies in analyzed time series.

Table 1. The ARIMA (p, d, q) models of ammonium concentration levels at the target water station.

\begin{tabular}{ccccc}
\hline ARIMA model & $\begin{array}{c}\text { Akaike } \\
\text { criterion } \\
\text { value }\end{array}$ & $\begin{array}{c}\text { Bayes } \\
\text { criterion } \\
\text { value }\end{array}$ & $\begin{array}{c}\text { RMSE } \\
\text { (error of } \\
\text { prediction) }\end{array}$ & $\begin{array}{c}\text { MAE } \\
\text { (error of prediction) }\end{array}$ \\
\hline ARIMA $(0,1,1)$ & 152.13 & 158.06 & 1.04 & 0.30 \\
ARIMA $(7,1,7)$ & 163.68 & 208.13 & 0.49 & 0.39 \\
\hline
\end{tabular}

Table 2. The ARIMA (p, d, q) models of phosphates concentration levels at the target water station.

* Corresponding author: drozdovigor94@gmail.com 
October 14-16, 2020

\begin{tabular}{lcccc}
\hline ARIMA model & $\begin{array}{c}\text { Akaike } \\
\text { criterion } \\
\text { value }\end{array}$ & $\begin{array}{c}\text { Bayes } \\
\text { criterion } \\
\text { value }\end{array}$ & $\begin{array}{c}\text { RMSE } \\
\text { (error of } \\
\text { prediction) }\end{array}$ & $\begin{array}{c}\text { MAE } \\
\text { (error of prediction) }\end{array}$ \\
\hline ARIMA $(1,1,1)$ & 32.21 & 41.1 & 0.68 & 0.44 \\
ARIMA $(1,1,4)$ & 37.55 & 55.32 & 0.42 & 0.41 \\
\hline
\end{tabular}

It is also appropriate to assume that values at stations 1 and 2, located upstream of target station, affect target station values. We can make use of this assumption to improve target values prediction accuracy by including station 1 and 2 values in forecasting model. We achieve this by constructing ArDL (Petrusevich, 2019; Kalugin et al., 2020; Nkoro and Uko, 2016) models. For ammonium time series ArDL model has following form, where $t$ denotes target time series and $\mathrm{x}$ denotes first station upstream:

$$
\hat{t}_{q}=-0.65 t_{q-1}-0.24 t_{q-2}+0.84 x_{p}+0.62 x_{p-1}+0.28 x_{p-2}+0.11 x_{p-3} .
$$

$\operatorname{ArDL}(3,3)$ and $\operatorname{ArDL}(4,4)$ models for phosphate time series:

$$
\begin{gathered}
\hat{t}_{q}=-0.76 t_{q-1}-0.48 t_{q-2}-0.18 t_{q-3}+0.48 x_{p}+0.26 x_{p-1}+0.35 x_{p-2} \\
\quad+0.21 x_{p-3} \\
\hat{t}_{q}=-0.81 t_{q-1}-0.62 t_{q-2}-0.33 t_{q-3}-0.23 t_{q-4}++0.52 x_{p}+0.35 x_{p-1} \\
\quad+0.46 x_{p-2}+0.33 x_{p-3}+0.21 x_{p-4} .
\end{gathered}
$$

Our presented analysis shows that statistical approach can be used to reveal environmental problems and, possibly, further mitigate them.

\section{REFERENCES}

V. Mokin, Ammonium prediction in river water. Retrieved from (the $1^{\text {st }}$ of September, 2020a): https://www.kaggle.com/vbmokin/ammonium-prediction-in-river-water

V. Mokin, Phosphate prediction in river water. Retrieved from (the $1^{\text {st }}$ of September, 2020b): https://www.kaggle.com/vbmokin/phosphate-prediction-in-river-water

Hyndman R. J. and Khandakar Y., 2008. Automatic time series forecasting: The forecast package for R. J. of Stat Software 27(3) pp 1-22 doi:10.18637/jss.v027.i03

Box G. and Jenkins G., 2008. Time series analysis: Forecasting and Control. John Wiley and Sons. 712 p ISBN13: $978-0470272848$

Petrusevich D., 2019. Time series forecasting using high order Arima functions. Proc XIX Int Multidisciplinary Scientific GeoConference SGEM 2019 19(2.1) pp 673-80 doi:10.5593/sgem2019/2.1/S07.088

Kalugin T. R. and Kim A. K. and Petrusevich D. A., 2020. Analysis of the high order ADL $(p, q)$ models used to describe connections between time series. Russ Tech J 8(2) pp 7-22 (In Russ) doi:10.32362/2500-316X2020-8-2-7-22

Nkoro E. and Uko A. K., 2016. Autoregressive Distributed Lag (ARDL) cointegration technique: application and interpretation J. of Stat and Econometric Methods 5(4) pp $63-91$ 


\title{
MATHEMATICAL MODELS OF WATER POLLUTION EVALUATION
}

\author{
I. Yu. Drozdov ${ }^{1 *}$, A. V. Aleksakhin ${ }^{2}$, Yu. V. Aleksakhina ${ }^{3}$, D. A. Petrusevich ${ }^{1}$ \\ ${ }^{1}$ Russian Technological University (MIREA), Moscow, 119454, Prospekt Vernadskogo, \\ 78, Russia \\ ${ }^{2}$ National University of Science and Technology "MISIS”, Moscow, 119049, Leninsky \\ Prospekt, 4, Russia \\ ${ }^{3}$ Moscow Polytechnic University, Moscow, 107023, Bol'shaya Semenovskaya, 38, Russia
}

Keywords: Time Series Analysis, Linear Regression, OLS, ARDL, Water Pollution

This paper aims to analyze water pollution in Ukraine using datasets provided by the Ukrainian government (Mokin, 2020a; Mokin, 2020b; Mokin, 2020c). We consider three indicators of water pollution: ammonium ions concentration, phosphate ions concentration and BOD. BOD (Biochemical Oxygen Demand) is the amount of dissolved oxygen, expressed in milligrams of oxygen per $\mathrm{dm} 3$ of water, consumed by micro-organisms to decompose the organic matter present in water.

All listed datasets are organized as time series of observations at eight consecutive water control stations. Only the data of the first three stations (target station, station \#1 and station \#2) is suitable for analysis (values at other stations are mostly unavailable).

Our first analysis is to explore dependencies between pollution indicators values at target station and stations 1 and 2, which are located further upstream. We are using linear regression, fitted with ordinary least squares (OLS), to predict value at target station using values at stations 1 and 2 as explanatory variables. With some feature engineering and R2 coefficient for model selection (James et al., 2015; Hastie, 2009) we constructed the following regression models:

$$
\begin{gathered}
\hat{t}_{a}=0.27+0.67 x_{1}+0.10 \ln x_{2} \\
\hat{t}_{p}=-0.51+1.87 x_{-} 1-0.55 x_{-} 1^{\wedge} 2-0.20 \ln \llbracket\left(x \_2 \rrbracket\right. \\
\hat{t}_{\text {bod }} 1.72+0.47 x_{1}+0.04 x_{1} x_{2}
\end{gathered}
$$

We have also explored dependencies between BOD time series and ammonium/phosphate concentration series. We have applied Granger test (Granger, 1980; Granger, 2001) to these series to check whether there is correlation between them. Results show that there is mutual dependence between ammonium and phosphate series and that BOD amount is strongly influenced by phosphate concentration. Using these results, we construct ArDL models (Hyndman and Khandakar, 2008; Hyndman and Athanasopoulos,

\footnotetext{
* Corresponding author: drozdovigor94@gmail.com
} 


\section{Book of abstracts \\ $\mathrm{XX}$ Conference of PhD Students and Young Scientists \\ October 14-16, 2020}

2018; Kalugin et al., 2020 Nkoro and Uko, 2016), which will describe how these series will depend on itself and other series over time. Fitted BOD models are:

$$
\begin{gathered}
B O D_{t}=-0.59 B O D_{t-1}-0.39 B O D_{t-2}-1.71 p_{t}-0.67 p_{t-1}-1.51 p_{t-2} \\
B O D_{t}=-0.70 B O D_{t-1}-0.57 B O D_{t-2}-0.29 p_{t-3}-1.45 p_{t}-0.36 p_{t-1} \\
\quad-1.14 p_{t-2}
\end{gathered}
$$

Ammonium / phosphate models are:

$$
\begin{aligned}
& \hat{\mathrm{a}}_{t}=-0.31 a_{t-1}-0.60 a_{t-2}+0.13 p_{t}+0.32 p_{t-1}+0.41 p_{t-2} \\
& \hat{p}_{t}=-0.82 p_{t-1}-0.32 p_{t-2}+0.06 a_{t}-0.04 a_{t-1}-0.13 a_{t-2}
\end{aligned}
$$

Judging from constructed models, we can make following conclusions:

- Phosphate and ammonium ions concentrations are correlated, suggesting underlying common cause for such pollutions

- Phosphate ion pollution contribute significantly to the increased BOD, while ammonium has much less influence

- ArDL models suggest that pollution is decreased over time.

\section{REFERENCES}

Mokin V., Ammonium prediction in river water. Retrieved from (the $1^{\text {st }}$ of September, 2020a): https://www.kaggle.com/vbmokin/ammonium-prediction-in-river-water

Mokin V., Phosphate prediction in river water. Retrieved from (the $1^{\text {st }}$ of September, 2020b): https://www.kaggle.com/vbmokin/phosphate-prediction-in-river-water

Mokin V., Prediction BOD in river water. Retrieved from (the $1^{\text {st }}$ of September, 2020c): https://www.kaggle.com/vbmokin/prediction-bod-in-river-water

James G. and Witten D. and Hastie T. and Tibshirani R., 2015. An introduction to statistical learning with applications in $R$ (Springer-Verlag New York) 426 p. doi: 10.1007/978-1-4614-7138-7

Hastie T. and Tibshirani R. and Friedman J., 2009. The elements of statistical learning (Springer-Verlag New York) $533 \mathrm{p}$

Granger C. W. J., 1980. Testing for causality: A personal viewpoint. J. of Economic Dyn and Control 2329 52

Granger C. W. J. 2001. Essays in Econometrics: The Collected Papers of Clive W.J. Granger Cambridge: Cambridge University Press

Hyndman R. J. and Khandakar Y., 2008. Automatic time series forecasting: The forecast package for R. J. of Stat Software 27(3) 1-22 doi:10.18637/jss.v027.i03

Hyndman R. J. and Athanasopoulos G., 2018. Forecasting: principles and practice. Otexts, 2 edition. $382 \mathrm{p}$ ISBN-13: 978-0987507112

Kalugin T. R. and Kim A. K. and Petrusevich D. A., 2020. Analysis of the high order ADL $(p, q)$ models used to describe connections between time series. Russ Tech J 8(2) 7-22 (In Russ) doi: 10.32362/2500-316X-2020$8-2-7-22$

Nkoro E. and Uko A. K., 2016. Autoregressive Distributed Lag (ARDL) cointegration technique: application and interpretation. J. of Stat and Econometric Methods 5(4) $63-91$ 


\title{
METHOD FOR DETERMINING THE LOADS ON THE DEFLECTION MODULE OF THE PUSH-THE-BIT ROTARY STEERABLE SYSTEM
}

\author{
A. Epikhin ${ }^{1}$, V. Zhironkin ${ }^{1 *}$, D. Szurgacz ${ }^{2}$, K. Trzop ${ }^{3}$ \\ ${ }^{1}$ National Research Tomsk Polytechnic University, 28 Vesennya st., 634034 Tomsk, Russia \\ ${ }^{2}$ KWK Ruda Ruch Bielszowice ul. Halembska 160, 41-711 Ruda Ślaska, Poland \\ ${ }^{3}$ KWK ROW Ruch Chwalowice, ul. Przewozowa 4, 44-206 Rybnik, Poland
}

Keywords: drilling, rotary steerable system, push-the-bit, deflecting blades, load reliability

The article presents a method for calculating the loads on the blades - elements of the deflecting module of the push-the-bit rotary steerable system for directional drilling of oil and gas wells, affecting its reliability. It is shown that the reliability of rotary steerable systems is of particular importance as the development of unconventional oil fields expands - a high-cost process that increases attention to specific factors of reliability of drilling equipment. A feature of the method for calculating the loads on the deflecting blades proposed by the authors is the representation of the rotary steerable system as an absolutely elastic rod, which is acted upon by a complex of forces arising from the directional wells with horizontal wavy segments. As a result of calculations, conditions were determined under which the interaction of forces acting on the deflecting blades will create a load close to the maximum permissible values, which increases the risk of failure of the entire bottomhole assembly of the rotary steerable system. The key condition was the change in the drilling segments of directional wells from ascending to descending when drilling a horizontal section with a wave profile, as a result of which there is a multiple load drop on the deflecting blades. Based on the calculated data, with an increase in the axial load, it is recommended to adjust the drilling mode to reduce the risk of failure of the push-the-bit rotary steerable system.

\footnotetext{
*Corresponding author: vsz14@tpu.ru
} 


\title{
EMPIRICAL FORMULATIONS FOR THE ESTIMATION OF DEFORMABILITY PARAMETERS OF ROCK MASSES BY MEANS OF DYNAMIC TESTING
}

\author{
N. Esteban ${ }^{1 *}$, R. A. Galindo ${ }^{1}$ \\ ${ }^{1}$ Universidad Politécnica de Madrid (UPM), ETSI Caminos, C. y P., C/ Profesor \\ Aranguren s/n, Madrid 28040, Spain
}

Keywords: rock mass, dynamic testing, deformability, empirical formulations

The estimation of the deformability parameters of rock masses is fundamental for the foundation assessment required in certain civil engineering projects. In recent times, the advantages of the characterisation methods involving dynamic testing have resulted in a progressive spread of their use. In this context, this report is meant to be a critical exposition of the fundaments of these dynamic methods, their advantages and limitations, as well as the empirical formulations for the estimation of deformability parameters of rock masses based on their results. Based on the results of recent studies, a discussion is made on the relationship between dynamic and static deformation moduli, and their dependency on factors such as lithology, weathering, or presence of discontinuity surfaces.

\footnotetext{
* Corresponding author: noelia.er.10@gmail.com
} 


\title{
NEW METHODOLOGY OF SIMPLIFIED ROCK TESTS TO DETERMINE BEARING CAPACITY IN EMBANKMENTS AND EXCAVATION BOTTOMS
}

\author{
C. L. Garrido ${ }^{1,2 *}$, I. Morilla ${ }^{3}$, R. A. Galindo ${ }^{1}$ \\ ${ }^{1}$ Departamento de Ingeniería y Morfología del Terreno, E T S I de Caminos, C y P, \\ c/Profesor Aranguren n ${ }^{\circ}$, Universidad Politécnica de Madrid, España \\ ${ }^{2}$ Fundación José Entrecanales Ibarra, E T S I de Caminos, C y P, c/Profesor Aranguren \\ $n^{\circ}$, Universidad Politécnica de Madrid, España \\ ${ }^{3}$ Departamento de Ingeniería Civil: Construcción, E T S I de Caminos, C y P, c/Profesor \\ Aranguren $n^{\circ} 3$, Universidad Politécnica de Madrid, España
}

Keywords: new methodology, simplified rock tests, bearing capacity, embankments, excavation bottoms.

Conventional rock tests are those commonly used in engineering works and projects, which allow the geotechnical and mechanical parameters of the rocks to be characterized, either through laboratory or in-situ tests. Although these tests are well-known and used in practice, they have the following drawbacks:

- They are very numerous and varied, being almost impossible to cover the entire range of procedures developed.

- There are lot of tests that are not standardized, making the results really difficult to homogenize and interpret.

- Many of the equipment needed is quite specific with limited availability, and when they can be used, they require highly qualified personnel.

- Results dispersion is remarkably high and involves a detailed interpretation.

- Both laboratory and in-situ tests are generally expensive, so in many cases not all necessary tests can be performed due to lack of budget.

- Execution times can be extended even for several months if it is a large work in a rock mass, such as highways or tunnels.

In this paper, new methodology of simplified rock tests is proposed to solve the main drawbacks of conventional rock testing and to provide useful results for practice applications (Morilla, 1992). A total of 16 tests have been developed divided into three categories: descriptive, resistance and inalterability tests. Every test has its own relative scoring system, with values between 0 and 5 and a brief description of each score. In summary, the general characteristics of these simplified tests are as follows:

- All of them can be performed in less than 24 hours (Morilla, 1994).

- They are simple tests that do not require highly qualified personnel.

\footnotetext{
*Corresponding author: carlosluis.garrido.garrido@gmail.com, carloslggarrido@gmail.com
} 


\section{Book of abstracts \\ $\mathrm{XX}$ Conference of PhD Students and Young Scientists \\ October 14-16, 2020}

- The equipment and tools used are conventional, portable, easy to acquire and operate.

- The cost of execution is extremely small compared to conventional rock tests.

- They are quite easy to evaluate thanks to the unique scoring system of each test.

- The results are quantitatively approximate, with lower accuracy than the most sophisticated conventional rock tests.

- Correlations have been developed to apply the scores directly in practice, thanks to extensive statistical series from other tests results (Morilla, 1992).

Among the main applications from this new methodology is the calculation of the bearing capacity in embankments and excavation bottoms, due to the lack of criteria or formulas that allow the use of test data directly in practice (Morilla, 1992). All 16 simplified rock tests must be done at least once to determine the bearing capacity as proposed. Tests results are grouped into two auxiliary parameters depending on whether they are more suitable to represent the resistance or the inalterability of the rock. Different ponderations are given to them depending if the bearing capacity is obtained for an embankment or an excavation bottom, while corrections must be applied in both situations to consider the insitu effects on the correlations. Final bearing capacity results do not include dimensions about their magnitude, but quantitative approximations about their range of application in embankments and excavation bottoms (Morilla, 1992).

\section{REFERENCES}

Barton N., Lien R. and Lunde J. 1975 Engineering classification of rock masses for design of tunnel support (Oslo: Norwegian Geotechnical Institute Publications).

Bell F. G. 1992. Engineering in rock masses. (London: Butterworth-Heinemann).

Bieniawski Z. T. 1992 Desing methodology in rock engineering. Theory, education and practice (Rotterdam: Balkema Publishers).

Hoek E. and Brady J. W. 1991. Rock slope engineering. (London: Institute of Mining and Metallurgy).

Morilla I. 1992. Determinación de las características geotécnicas de las rocas mediante ensayos simplificados. (Madrid: E T S I de Caminos, Canales y Puertos. Universidad Politécnica de Madrid. Departamento de Ingeniería Civil-Construcción).

Morilla I. 1994. Metodología para determinar la alterabilidad de los suelos y rocas mediante inmersión en varios electrolitos. (Madrid: E T S I de Caminos, Canales y Puertos. Universidad Politécnica de Madrid. Departamento de Ingeniería Civil-Construcción). 


\title{
IMPACT OF TRANSIENT LUMINOUS EVENTS ON THE CHEMISTRY OF ATMOSPHERE AS A SPECIAL CASE OF THE IMPACT OF THUNDERSTORMS
}

\author{
P. Jujeczko ${ }^{1 *}$ \\ ${ }^{1}$ Space Research Centre of the Polish Academy of Sciences, \\ Bartycka 18A, 00-716, Warsaw, Poland
}

Keywords: sprite, Transient Luminous Event, streamer, NOx, greenhouse gas

Since climate changes can increase the number of severe thunderstorms (Brooks, 2013), the influence of thunderstorm-related greenhouse gases production may become more meaningful in the future. Already, the contribution to the production of NOx by lightnings is $\sim 7 \mathrm{Tg}$ per year, i.e. it is a value comparable to biomass-burning-related production which is $\sim 8 \mathrm{Tg} /$ year (Schumann and Huntrieser, 2007). Transient Luminous Events (TLEs) are various forms of electric optical phenomena that occur above thunderstorms. Their first appearance was registered in 1989 (Franz et al., 1990) and since then many different types of TLEs were discovered, e.g. sprites, jets, elves, halos and others (Surkov and Hayakawa, 2020 ) - see Figure 1. Although they last for a very short time ( 100 ms), TLEs are often spatially large - a typical single sprite is $\sim 10 \mathrm{~km}$ high, while sprite-clusters are often as wide as $\sim 40 \mathrm{~km}$ (Rakov and Uman, 2003, p. 487). TLEs contribute to various chemical processes in the atmosphere, such as production of NOx, N, N2O, CO2 (Parra Rojas et al., 2015; Pérez-Invernón et al., 2020, p.). By this, they affect the greenhouse gases concentration on the altitudes where the air pollution by human activity is less pronounced (i.e. in stratosphere, mesosphere, thermosphere). Despite the fact that lightnings are more energetic than most of the TLEs, sprites can contribute to a production of about $9.7 \times 10^{20}$ atoms of $\mathrm{N}$, $5.9 \times 10^{19}$ molecules of NO, and $1.2 \times 10^{18}$ molecules of $\mathrm{N} 2 \mathrm{O}$ on mesospheric altitudes, per a single event (Pérez-Invernón et al., 2020).

This work has been supported by the National Science Centre grant No. 2017/27/B/ST10/02285

*Corresponding author: pjujeczko@cbk.waw.pl 


\section{Book of abstracts \\ $\mathrm{XX}$ Conference of PhD Students and Young Scientists \\ October 14-16, 2020}

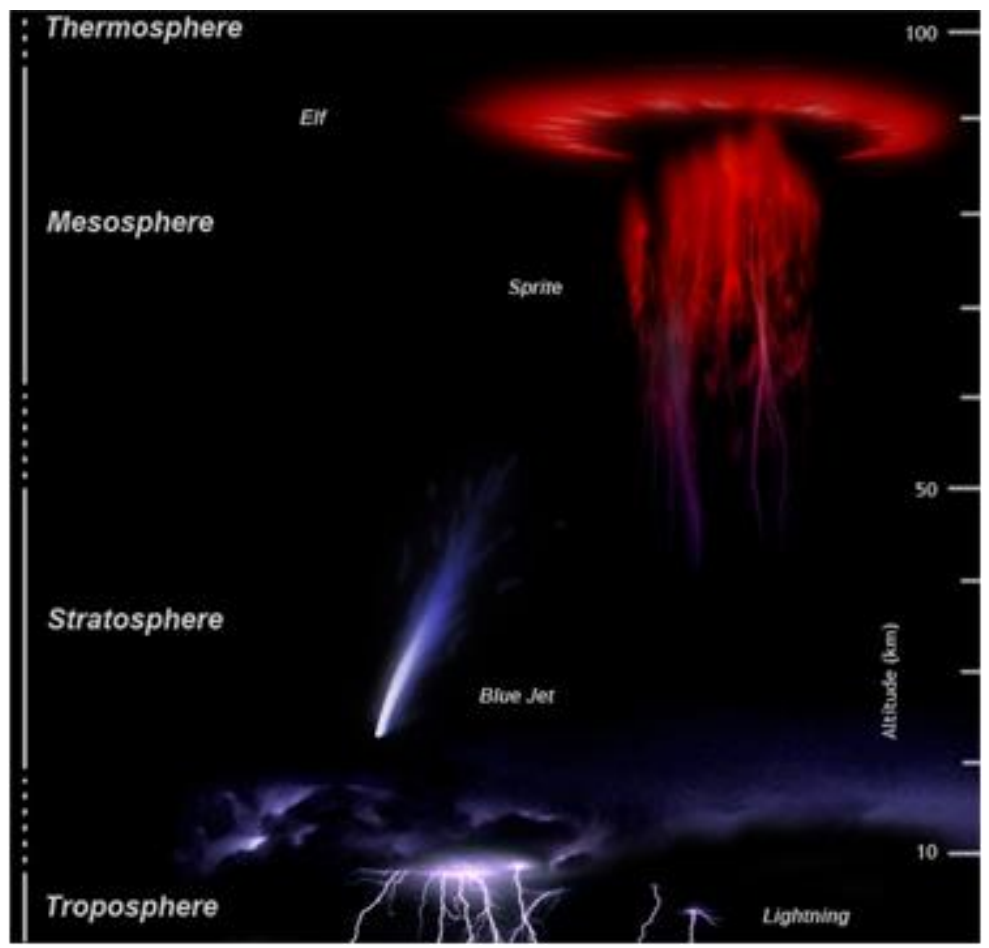

Figure 1: Graphics illustrating several types of atmospheric discharges with their altitude and scale.

(Abestrobi, 2008)

\section{REFERENCES}

Abestrobi. (2008). Own work, CC BY-SA 3.0, https://commons.wikimedia.org/w/index.php?curid=4262250.

Brooks, H. E. (2013). Severe thunderstorms and climate change. Atmospheric Research, 123, 129-138. https://doi.org/10.1016/j.atmosres.2012.04.002

Franz, R. C., Nemzek, R. J., and Winckler, J. R. (1990). Television image of a large upward electrical discharge above a thunderstorm system. Science. https://doi.org/10.1126/science.249.4964.48

Parra Rojas, F. C., Luque Estepa, A., Gordillo Vázquez, F. J., and Instituto de Astrofísica de Andalucía. (2015). Electrical discharges in planetary upper atmospheres: Thermal and chemical effects. Universidad de Granada ; Instituto de Astrofísica de Andalucía.

Pérez-Invernón, F. J., Malagón-Romero, A., Gordillo-Vázquez, F. J., and Luque, A. (2020). The Contribution of Sprite Streamers to the Chemical Composition of the Mesosphere-Lower Thermosphere. Geophysical Research Letters, 47(14). https://doi.org/10.1029/2020GL088578

Rakov, V. A., and Uman, M. A. (2003). Lightning: Physics and Effects. Cambridge University Press. https://books.google.com.eg/books/about/Lightning.html?id=Urz3CwAAQBAJ\&printsec=frontcover\&sou rce=kp_read_button\&redir_esc $=\mathrm{y} \# \mathrm{v}=$ onepage $\& \mathrm{q} \& \mathrm{f}=\mathrm{false}$

Schumann, U., and Huntrieser, H. (2007). The global lightning-induced nitrogen oxides source. Atmos. Chem. Phys., 85.

Surkov, V. V., and Hayakawa, M. (2020). Progress in the Study of Transient Luminous and Atmospheric Events: A Review. Surveys in Geophysics. https://doi.org/10.1007/s10712-020-09597-2 


\title{
A REVIEW OF THE GEOCHEMICAL CHARACTERISTICS OF THE NIEMSTÓW-WIELOWIEŚ AREA AND ITS EXPLORATION SIGNIFICANCE, LOWER SILESIA, POLAND
}

\author{
W. Kaczan ${ }^{1 *}$, H. Wirth ${ }^{1}$ \\ ${ }^{I}$ Wroclaw University of Science and Technology, Faculty of Geoengineering, Mining, and \\ Geology, 27 Wybrzeże Wyspiańskiego St., 50-370 Wroclaw, Poland
}

Keywords: Wielowieś, Niemstów, copper, Poland, copper equivalent

The exploration works within the area Niemstów-Wielowieś took place between 2012 and 2013 and were conducted by Balamara Resources Limited. The described region is situated around $10 \mathrm{~km}$ from Lubin (Lower Silesia, Poland) and is neighboring to the Lubin Mine owned by KGHM Polska Miedź S.A. The average copper content in the ore of the Lubin-Małomice deposit is $0.95 \%$ and silver $48 \mathrm{~g} / \mathrm{Mg}$ [1]. Considering the localization of Niemstów-Wielowieś, its closeness to the documented stratabound type copper deposit with significant metal content, and to the active mine, it gave a reasonable point for conducting the exploration campaign. Works resulted in the chemical analyses of the most promising drill core parts for five drill holes (Bogdan-1, Bogdan-2, Bogdan-4, Bogdan-7, and Bogdan10; Figure 1).

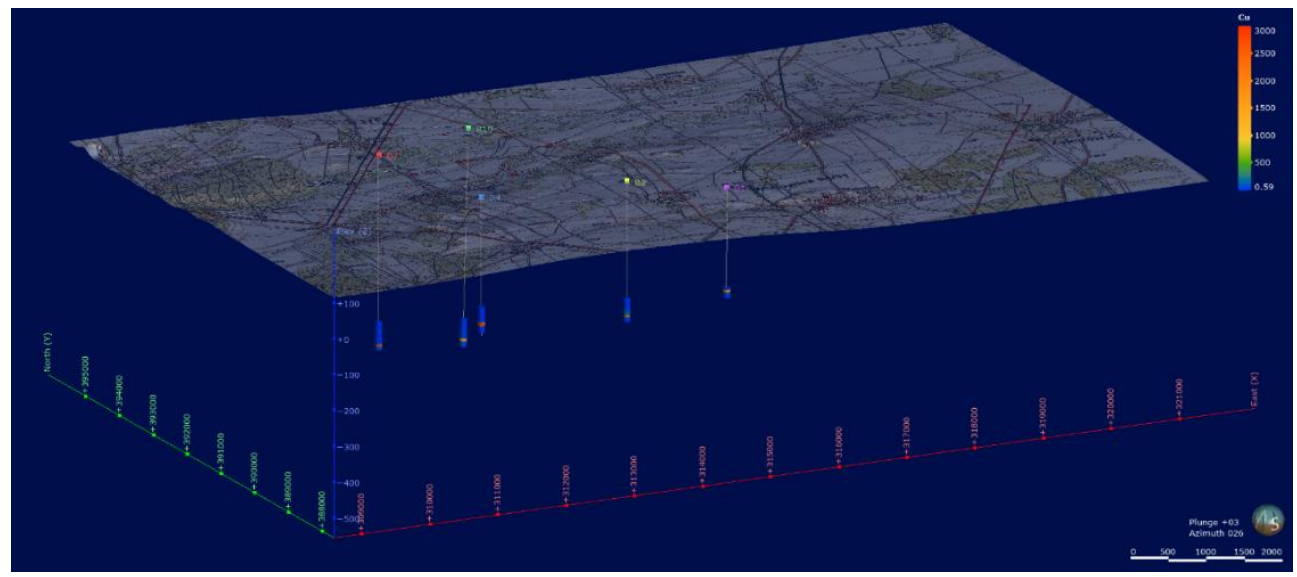

Figure 1. The distribution, depth, and copper content of the drill holes; exaggerated Z-axis 5x (made with Leapfrog Geo)

The highest obtained $\mathrm{Cu}$ content exceeds $1 \%$, however it was observed only in a short interval of drill core. In all drillholes were noticed the anomalies of copper, silver, lead, zinc

* Corresponding author: wojciech.kaczan@pwr.edu.pl 


\section{Book of abstracts \\ $\mathrm{XX}$ Conference of PhD Students and Young Scientists \\ October 14-16, 2020}

and cobalt. The enriched zone was mainly related to the cuprous shale. However, because of the not economically satisfactory results, the exploration campaigne did not end up with a mining activity yet. The authors introduce the main information about the region and the exploration campaigne. Moreover, they discuss the obtained geochemical profiles for all drillholes. The analyzed project is put into the perspective of current metal stock prices and is estimated with the use of basic copper equivalent value.

\section{REFERENCES}

KGHM Official Website https://kghm.com/en/our-business/mining-and-enrichment/lubin (accessed 1 September 2020).

Leapfrog Geo (Seequent), https://www.seequent.com/products-solutions/leapfrog-geo/ (accessed 1 September 2020) 


\title{
DEVELOPMENT OF EXTRATERRESTRIAL RESOURCES' EXTRACTION - PREREQUISITES FOR THE FORMATION OF A NEW SCIENTIFIC DISCIPLINE
}

\author{
A. M. Khairutdinov ${ }^{1}$, Y. Tyulyaeva ${ }^{2}$, Ch. Kongar-Syuryun ${ }^{3 *}$, A. Rybak ${ }^{4}$ \\ ${ }^{1}$ RUDN University, Miklukho-Maklaya Str. 6, 117198, Moscow, Russia \\ ${ }^{2}$ Florida Int. University, 11200 SW 8th Street, AHC-5 360 Miami, FL 33199, USA \\ ${ }^{3}$ NUST MISIS, Leninsky Av. 4, 119991, Moscow, Russia \\ ${ }^{4}$ Wrocław University of Sci. and Tech., Wyb. Wyspiańskiego 27, 50-370 Wrocław, Poland
}

Keywords: extraterrestrial resources, mineral extraction, outer space exploration

An industrial society cannot do without the consumption of natural resources. The production activity of the mining complex has a significant impact on the environment. At present, the impact of human activity in general and the economic consequences of the impact of mining in particular on the environment has reached dimensions commensurate with the impact of natural, natural processes on Earth. In this regard, the prerequisites arose for the termination of mining on Earth and the search for new sources of natural resources (Volynskaya, 2016). The demand for mineral raw materials is only growing, and the development of extraterrestrial resources is seen as inevitable. The closest and most studied object is the Moon, but there are many asteroids containing valuable materials (Slyuta, 2017). In addition to economic, technical and technological issues arising in the development of minerals on celestial bodies, there are legal aspects to be resolved (Khayrutdinov, 2018). Under the Outer Space Treaty (1967) and the Moon Agreement (1979), states undertake to establish an international regime to regulate the exploitation of the moon's natural resources when it is clear that such exploitation will become possible. Every year, private corporations play an increasing role in the development of extraterrestrial resources, and general rules of regulation of activities are not enough. There are contradictory opinions of scientists regarding the commercial use of resources mined in space bodies. The discrepancies have intensified after the issuance of the Executive Order on Encouraging International Support for the Recovery and Use of Space Resources by President Trump on April 7, 2020. It is proposed to change the ownership of extracted extraterrestrial resources, which changes the pre-existing laws. The adopted Artemis Accords program assumes the creation of "safety zones" on the celestial bodies of each state or corporation operating in a given place (Zhukova and Abashidze, 2020).

The global interest in the mineral resource base of celestial bodies is justified. If territorial disputes were previously known: land; seas; oceans, then it turns into the vector of development of global conflicts: into cyberspace (Internet) and outer space, which until now remains insufficiently explored, although not a new space. Consequently, at this stage,

* Corresponding author: cheyneshkongarsyuryun@gmail.com 


\section{Book of abstracts \\ $\mathrm{XX}$ Conference of PhD Students and Young Scientists \\ October 14-16, 2020}

the prerequisites for the beginning of the global development of the mineral resource base of extraterrestrial resources have emerged. It should be noted that the issue of extracting useful components on celestial bodies is not a monodisciplinary one, and research in various industries is rather scattered and does not have a clear link. When extracting a mineral from the subsoil, there is science, geotechnology, which unites many disciplines.

At the same time, geotechnology acts as a kind of connecting-controlling science, which, based on the scientific achievements of each separate science, develops independently, taking into account the needs, problems and experience of the mining industry, develops sectors of each of the sciences separately. The development of the mineral resources of celestial bodies do not have development experience. In addition, there is no unified systematization of all scientific research, with a unified interpretation and terminology. The extraction of minerals from celestial bodies has not yet been identified as a separate scientific direction. The lack of a unified picture does not allow to combine the acquired knowledge into a single whole and determine a consolidated path of development. The first stage in the formation of a new science or a new scientific direction is the selection of a new object of scientific research.

When developing the mineral resource base of celestial bodies, the science that studies the methods and processes of its development, creating the theoretical foundations and engineering solutions for effective and economically viable extraction, is planetary technology or astrotechnology. Astrotechnology (from the ancient Greek words: $\alpha$ $\sigma \tau \rho o v$ star; $\tau \dot{\varepsilon} \chi \vee \eta$ - art, skill, skill; $\lambda o ́ \gamma o \varsigma$ - word, thought, meaning, concept) is a completely natural and understandable name for a new scientific direction, which sets the task of studying and developing technologies for extracting minerals from cosmic bodies.

\section{REFERENCES}

Volynskaya O.A., 2016. Commercial use of space resources as the main challenge for international space law. Sovremennye problemy mezhdunarodnogo kosmicheskogo, vozdushnogo i morskogo prava: Materialy kruglogo stola XIV Mezhdunarodnogo kongressa «Blishchenkovskie chteniya» Internauka Publ.: RUDN, $118-136$

Slyuta E.N., 2017. The main types of lunar resources and the problems of their extraction and enrichment. Gornyi zhurnal, No. 4, 13-18 [In Russ]

Khayrutdinov A.M., 2018. Actual problems of the extraction of natural resources on celestial bodies. Pravovoe regulirovanie obshchestvennykh otnoshenii na zemle i $\mathrm{v}$ kosmicheskom prostranstve: Materialy mezhdunarodnoi nauchno-prakticheskoi molodezhnoi konferentsii, 234-235 [In Russ]

Zhukova G.P., Abashidze A.Kh., 2020. International space law. Internauka Publ Yurait 527 p. 


\title{
MOVING TOWARDS SUSTAINABLE MINING THROUGH SPARING GEOTECHNOLOGY
}

\author{
A. Khairutdinov ${ }^{1 *}$, A. Ubysz ${ }^{2}$, A. Adigamov ${ }^{1}$ \\ ${ }^{1}$ National University of Science and Technology MISIS, Leninsky Av. 4, 119991, Moscow, \\ Russia \\ ${ }^{2}$ Wroctaw University of Science and Technology, Wyb. Wyspiańskiego 27, 50-370 \\ Wroctaw, Poland
}

Keywords: geotechnology, sustainable mining, backfilling, industrial waste, ecology

Man-made disasters during the extraction of minerals occur more frequently. One of the ways to minimize man-made disasters is the use of technology with backfilling of working space (Khayrutdinov et al., 2020).

The use of backfilling of working space allows you to control mining pressure and increase the safety of mining operations as well as simultaneous mining of the deposit by underground and open methods. This increases the recovery rate, and also reduces the negative impact of mining on the environment (Khairutdinov and Tyulyaeva, 2019). Despite the advantages of underground geotechnology with the backfilling, it at the same time increases the cost of mining and requires the improvement of the relevant processes.

The use of backfill in mining operations is associated with the construction of backfill complexes. They require significant financial costs as well as complicate the technological scheme of the process of mining. As can be seen, the use of technologies with backfilling is associated with significant costs and is effective in developing more valuable ores (Khayrutdinov et al., 2020).

The use of local natural materials and waste products will significantly reduce the costs not only for backfilling, but also for the maintenance of various types of dumps and tailings. The rational use of elements of backfilling with disposal will significantly reduce the cost of the process and allow to effectively develop less valuable mineral deposits. Studies on the formation of backfill arrays on the basis halite tailings of enrichment showed that, if there are appropriate activation methods, they can be successfully used as aggregate (Khairutdinov and Tyulyaeva, 2019).

An important characteristic of the backfilling is the dynamics of strength in time. The pattern of growth of strength is important in determining the minimum time to start working out of the pillars. This affects the choice of parameters for development systems. Characteristics of the future backfill array largely depend on the properties of the source materials. Therefore, their correct choice is one of the most important factors in the backfill technology.

\footnotetext{
* Corresponding author: khayrutdinov.albert99@gmail.com
} 


\section{Book of abstracts \\ $\mathrm{XX}$ Conference of PhD Students and Young Scientists \\ October 14-16, 2020}

The setting time of the filling mass should not be less than the required time for delivery of the mixture to the space developed. As in this case, the stratification leads to an uneven distribution of the constituent components in the developed space and also to the heterogeneity of the artificial array and reduced strength. A series of experiments allowed to determine the influence of the content of magnesian cement in the backfill on its strength. For comparison, samples of hydraulic backfill were simultaneously produced. All tests were carried out according to the standard procedure (1990).

The results of testing the strength of the uniaxial compression are given in Figure 1.

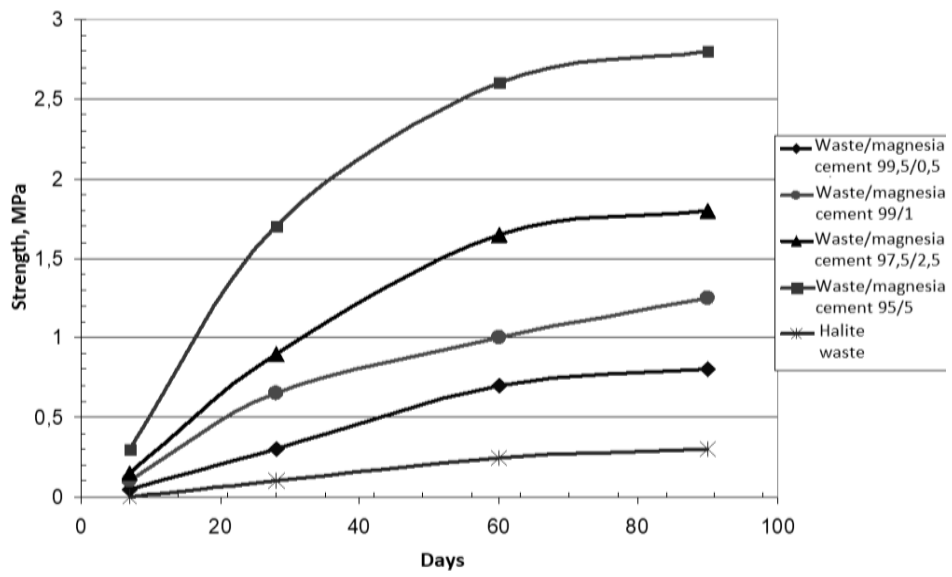

Figure 1. The kinetics of backfilling strength with different binder content

When choosing a technology for extracting minerals from the depths, it is necessary to take into account a combination of many factors: economic, environmental and safety. The use of technology with the backfilling of working space on the basis of man-made waste, allows for more efficient use of natural resources and implies the transition from measures of an exclusively protective nature to the planned management of natural resources and the use of waste-free geotechnology.

\section{REFERENCES}

Khairutdinov A.M., Tyulyaeva Y.S., 2019. Extraction of minerals on celestial bodies. Background, technological aspects and legal framework. Problems of subsoil development in the 21st century through the eyes of young people: materials of the 14th International Scientific School of Young Scientists and Specialists, 280-283.

Khayrutdinov M.M., Kongar-Syuryun Ch.B., Tyulyaeva Y.S., Khayrutdinov A., 2020. Planetary Technology. Prerequisites for the Formation of a New Scientific Discipline. Russian Mining Industry, No. 3, 113-120. Methodological recommendations for quality control of backfilling mixtures, 1990. Apatity: MI KSC RAS. 


\title{
STOPE STABILITY ASSESSMENT BY THE MATHEWS-POTVIN METHOD: A CASE-STUDY OF OPEN STOPING IN SALT ROCK MASS UNDER CONDITIONS OF SECONDARY STRESS FIELD
}

\author{
Ch. V. Khazhyylai ${ }^{1}$, M. A. Kosyreva ${ }^{1}$, V. A. Eremenko ${ }^{1 *}$, A. R. Umarov ${ }^{1}$ \\ ${ }^{1}$ National University of Science and Technology MISIS, Leninsky Av. 4, 119991, Moscow, \\ Russia
}

Keywords: Mathews-Potvin stability graphs, stope, hydraulic radius, Q-system, Barton's method, RQD, open stoping

Predicting the stability of open stopes is a challenging task for underground mine engineers. The introductory part of this paper presents main issues related to stability and safety of soil and rock mass in course of large earthworks and underground works. On the basis of former studies, this paper reviews the research findings on stope stability by the methods of Mathews and Potvin in the stoping design for rock salt mines operating at depths greater than $1 \mathrm{~km}$ under conditions of secondary stress fields, as well as the rock mass quality assessment by Barton's method. The conservative stope design has been performed for a few scenarios of design parameters. In conclusions, it is underlined by the stability graph at the given parameters, that in the first case-study scenario, HR is $4.5 \mathrm{~m}$ and the Mathews-Potvin stability number is $68 \mathrm{~m}$. It is concluded that the stopes will be stable and preserve their shapes. On the basis of presented case study (stope stability assessment in the test halite-polyhalite-polymineral salt deposit was carried out for a few scenarios at maximal effective stresses and under conditions of jointing), the authors provide the general provisions on salt rock mass assessment at great depths.

Design and predicting the stability of open stopes is a challenging task for underground mine engineers. On the basis of former studies, this paper reviewed the research findings on stope stability by the methods of Mathews and Potvin in the stoping design for rock salt mines operating at depths greater than $1 \mathrm{~km}$ under conditions of secondary stress fields, as well as the rock mass quality assessment by Barton's method. The conservative stope design has been performed for a few scenarios of design parameters. On the basis of presented case study (stope stability assessment in the test halite-polyhalite-polymineral salt deposit was carried out for a few scenarios at maximal effective stresses and under conditions of jointing), the authors provided the general provisions on salt rock mass assessment at great depths.

\footnotetext{
* Corresponding author: prof.eremenko@gmail.com
} 


\title{
MODELS AND ALGORITHMS OF CHOICE OF DEVELOPMENT TECHNOLOGY OF DEPOSITS WHEN SELECTING THE COMPOSITION OF THE BACKFILLING MIXTURE
}

\author{
Ch. Kongar-Syuryun ${ }^{1 *}$, A. Ubysz ${ }^{2}$, V. Faradzhov ${ }^{1}$ \\ ${ }^{I}$ National University of Science and Technology MISIS, Leninsky Av. 4, 119991, Moscow, \\ Russia \\ ${ }^{2}$ Wrocław University of Science and Technology, Wyb. Wyspiańskiego 27, 50-370 \\ Wrockaw, Poland
}

Keywords: geotechnology, backfill mixture, integral indicators, methodology

The complexity of the choice of development methods and systems technology creates the need to create models and algorithms when selecting the compositions of the filling mixture. About $35 \%$ of mines use systems with backfilling (Khayrutdinov, 2007). At present, when creating backfill mixtures, the development of fundamentally new materials.

The complexity and laboriousness of the process of selecting the backfill parameters and the composition of the backfill mixture does not allow detailed elaboration of several variants and compositions, which does not guarantee an optimal decision. This is a prerequisite for the widespread use of methodological, algorithmic and mathematical methods in geotechnology. This methodology is intended to provide assistance in finding discrepancies from the generally accepted systematic and consistent rules for calculating technological and economic provisions. For a more accurate and detailed disclosure of the true advantages of technical and economic indicators and technological solutions, it is necessary to consider and compare moderately similar mining enterprises.

As a result, 13 parameters (factors) of the conditions of occurrence and development of deposits were identified, which have the greatest impact on the choice of design and technological values, filling parameters and the choice of the filling mixture composition.

The most important integral indicators of the application of a certain extraction technology are traditionally considered to be the service life of a deposit $(\mathrm{T})$ and the cost of extracting a mineral resource (C) and the reliability and safety (technological and environmental) of the applied technology (E) at a particular deposit is the most important indicator. The content of the design solution is presented by the structural model of the project in Figure 1.

Thus, each design option (D) can be represented as the following information structure:

$$
D_{i}\left\{U_{1 i}, U_{2 i}, U_{3 i}, S_{i}, Z_{i}, G_{i}, C_{i}, T_{i}, E_{i}\right\}
$$

\footnotetext{
*Corresponding author: cheyneshkongarsyuryun@ gmail.com
} 


\section{Book of abstracts \\ XX Conference of PhD Students and Young Scientists \\ October 14-16, 2020}

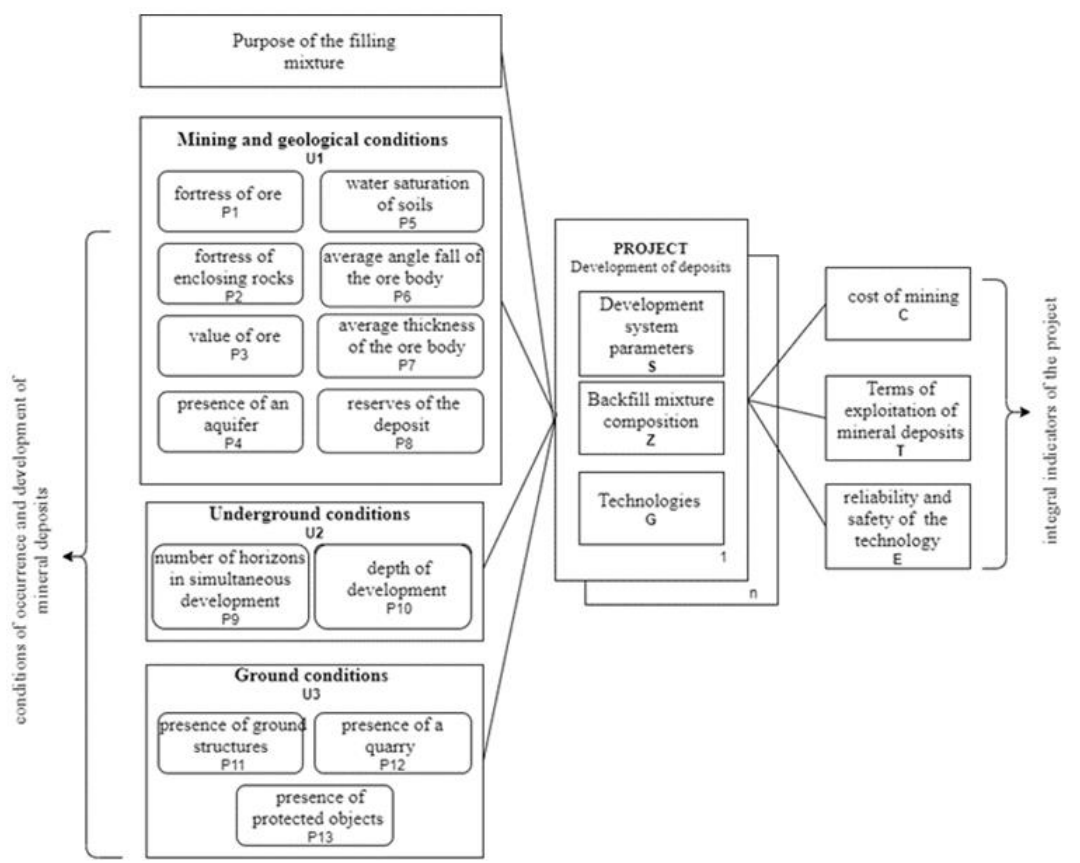

Figure 1. Structural representation of the project model for the development of mineral deposits

With such a program, an important task is resolved - an objective assessment of the quality of the completed project (Tomilin, 2016).

In the algorithms, it is necessary to express the existing relationships between mining and geological, technical, economic, environmental parameters and the functionality of the project with the "standard" (Malkin et al., 2000). Often, some of the indicators exceed the "standard", some are below. In this case, the methodology must present alternative compared groups in a uniform assessment system. Comparison with the existing mines is impossible, as there is no exact analogy. Consequently, it is difficult to understand which of the factors of the established mining and geological conditions to a greater or lesser extent affects the technical and economic indicators.

Proposed to enter a coefficient of relative importance for each factor. The coefficient of relative importance is needed to increase or decrease the influence of this factor in the algorithm.

To exclude the subordination of the range-point value judgment, it is necessary to calculate the reliable values of the coefficients of significance of technical and economic performance indicators. Significance coefficients of technical and economic performance indicators are calculated once, and the obtained values can be used for a rather long time.

The use of the developed methodology and algorithms will make it possible to create a software product that, at the initial stages, will be able to provide significant assistance in 


\section{Book of abstracts \\ XX Conference of PhD Students and Young Scientists \\ October 14-16, 2020}

the design, and subsequently, it may be able to independently carry out the design of mining enterprises.

\section{REFERENCES}

Khayrutdinov M.M., 2007. Ways to improve development systems with laying the developed space. Gornyi Zhurnal, No. 11, 40-43.

Malkin A.S., Puchkov L.A., Salamatin A.G., Eremeev V.M., 2000. Mine Design. Internauka Publ Akademii gornykh nauk.

Tomilin A.V., 2016. Creating a feasibility study for the design of underground structures using expert systems. Natural and technical sciences, No. 4(94), 228-232. 


\title{
AREAS OF NATURAL CONFLICTS IN HARMONIZED THEMATIC MAPS OF THE STRZELIN COUNTY
}

\author{
P. Kozińska ${ }^{1 *}$, A. Górecki ${ }^{1}$ \\ ${ }^{1}$ Wroclaw University of Science and Technology, Wybrzeże Wyspiańskiego 27 \\ 50-370 Wroctaw, Poland
}

Keywords: natural conflict, thematic map, harmonization, soil - geological map, Strzelin County

Recently in Poland, there has been a strong emphasis on data harmonisation, which means data coherence, mainly spatial. The reason for this is the INSPIRE Directive (Dz.U. L 108 z 25.4.2007, p. 1-14) approved in 2007 and the Spatial Information Infrastructure Act (Dz. U. $2010 \mathrm{Nr} 76$ poz. 489) implemented on the basis of this Directive in Poland in 2010. On this basis, the aim of this study was to make the data from soilagricultural maps and geological maps coherent, so that no natural conflicts would arise. The study was based on materials concerning soil classification and lithology, which are soil-agricultural and geological maps, but also on isohips. The method, which was applied, consisted in combination of attributes of the maps, then natural conflicts were identified, that is lack of smooth transition from soils to lithology - a given soil would not be able to develop on the indicated geological substratum. A significant part of the identified conflicts required editing, however some of them can be treated as exceptions. The reason for such discrepancies is the lack of precise information on the deposited layers at the depth of $1.5 \mathrm{~m}-2.0 \mathrm{~m}$, which results from the measurement methods of the analysed maps. The last step was to eliminate these conflicts in order to generate consistent and harmonised data. As a result, a list of attributes of full compatibility was obtained, thanks to them maps of any parameters can be generated, and also a basis for presenting soils in a different systematics.

\section{REFERENCES}

Dyrektywa 2007/2/WE Parlamentu Europejskiego i Rady z dnia 14 marca 2007r. ustanawiająca infrastrukturę informacji przestrzennej we Wspólnocie Europejskiej (INSPIRE) (Dz.U. L 108 z 25.4.2007, s. 1-14) Ustawa z dnia 4 marca 2010r. o infrastrukturze informacji przestrzennej (Dz. U. $2010 \mathrm{Nr} 76$ poz. 489)

\footnotetext{
* Corresponding author: patrycja.kozinska@pwr.edu.pl
} 


\title{
IDENTIFICATION OF AREAS AT RISK OF HYDROGEOLOGICAL DROUGHT IN THE BIALA LĄDECKA RIVER BASIN (SUDETES MOUNTAINS, POLAND)
}

\author{
A. Kozłowska ${ }^{1 *}$ \\ ${ }^{1}$ Wroctaw University of Science and Technology, Wyb. Stanisława Wyspiańskiego 27, \\ 50-370 Wroctaw
}

Keywords: groundwater potential, hydrogeological drought, climate change, multicriteria analysis

The problem of hydrogeological drought, i.e. the state that consists in a long-term reduction of groundwater resources, is an extremely important and recent problem. The primary issue that should be addressed is the identification of areas susceptible to this phenomenon.

This research presents a multi-criteria analysis of natural factors influencing the rainwater infiltration in the mountainous river basin. The analysis covers the catchment of the Biała Lądecka river, which is located in south-western Poland, in the Eastern Sudetes macroregion. In this approach, in terms of impact on groundwater recharge, the geological and soil conditions, the density of the river network and lineaments, the slope and land use as well as the amount of precipitation are assessed. Based on the evaluation of the interaction between the factors, global weights are established, and the internal classifications of the individual factors are the local weights for weighted overlay analysis in GIS software. As a result, an assessment of the area's susceptibility to the phenomenon of hydrogeological drought is obtained and its risk zones are designated.

\section{REFERENCES}

Kowalczyk A. Niżówka hydrogeologiczna - przyczyny i skutki. Technologia Wody, Nr 49:5, 2016

Machiwal D., Jha M. K., Mal B. C. Assessment of groundwater potential in a semi-arid region of India using remote sensing, GIS and MCDM techniques. Water Resource Management. 25(5), 2011, 1359-1386

Waikar M.L., Nilawar Aditya P. Identification of Groundwater Potential Zone using Remote Sensing and GIS Technique. vol. 3(5): 2014.

\footnotetext{
*Corresponding author: aleksandra.kozlowska@pwr.edu.pl
} 


\title{
A RATIONAL APPROACH TO THE MANAGEMENT OF UNDERGROUND MINING IN COMPLEX HYDROGEOLOGICAL AND GEOMECHANICAL CONDITIONS BASED ON A RISK ASSESSMENT
}

\author{
E. Krasyukova ${ }^{1 *}$, I. Aynbinder ${ }^{1}$, A. Ivannikov ${ }^{2}$ \\ ${ }^{1}$ Institute of Comprehensive Exploitation of Mineral Resources Russian Academy of \\ Sciences, Kryukovskiy Tupik 4, 111020, Moscow, Russia \\ ${ }^{2}$ National University of Science and Technology MISIS, Leninsky Av. 4, 119991, Moscow, \\ Russia
}

Keywords: geomechanical risk, risk matrix, hazardous zones, crown pillar, open-pit mining, groundwater

Currently, the approach to the design and development of deposits is reduced mainly to the generally accepted consideration of mining conditions and the selection of development systems and technologies on this basis, considering also the economic efficiency of mining (Kaplunov D.R., 2014). So, in most cases, vertical and subvertical ore bodies with access to the earth's surface are developed by a combined mining method. The conditions of occurrence of such ore bodies are determined by mining operations at great depths, where the most acute problems are development of deposits under conditions of high rock pressure, gas and hydrodynamic phenomena (Aynbinder I.I. et al., 2019).

In this paper, the problems that arise during the combined development of vertical and subvertical ore bodies under complex hydrogeological and geomechanical conditions are considered, and their influence on the safety of mining operations is analyzed. In the course of the research, using the example of kimberlite deposits in Yakutia, new mechanisms were identified and spatial patterns were established for the development of processes of deformation, displacement and destruction of ore and rock masses during preparatory excavations and treatment works near surface and underground water bodies, including high-pressure ones. Adjusted the design scheme, which is based on the mechanism of collapse development, in which the destruction of rocks occurs under the influence of its own weight due to weak ties of structural blocks to each other (Carter T. G., 2014).

The mechanisms of complex accounting of the structural state of the massif, preliminary technogenic impact, the effect of complicating mining and geological and hydrogeological factors in substantiating the parameters of hazardous zones and barrier pillars are proposed.

Risk assessment method based on hazard identification, a qualitative and quantitative analysis of the likelihood of an emergency considering the severity of the consequences when conducting mining in hazardous areas is presented. As a result of the analysis, it became possible to develop effective compensation measures aimed at reducing the development of self-collapse processes in the lower part of the pillar and preventing

\footnotetext{
*Corresponding author: krasyukovaev@ipkonran.ru
} 


\section{Book of abstracts \\ XX Conference of PhD Students and Young Scientists \\ October 14-16, 2020}

the development of dome formation processes, which made it possible to provide an acceptable level of risk for the time of working out the under-quarry part of the kimberlite pipe.

The application of the method in combination with the timely adjustment of technological processes provides a rational integrated use of geo-resources in the framework of sustainable development of mining system.

\section{REFERENCES}

Aynbinder I.I., Kaplunov D.R. Risk-based approach to selection of deep-level mining technology. Mining Informational and Analytical Bulletin. 2019, No 4, pp. 5-19.

Carter T.G., 2014 Guidelines for use of the Scaled Span Method for Surface Crown Pillar Stability Assessment. Available online: https://www.rocscience.com/help/cpillar/pdf_files/papers/Trevor_Carter_2014.pdf

Hebblewhite B., 2019 Geotechnical risk in mining methods and practice: critical issues and pitfalls of risk management. Mining Geomechanical Risk, Perth, Australia

Kaplunov D.R. Development of a theoretical basis of mining enterprises design. Gornyy zhurnal. 2014, no 7 , pp. 49-51. [In Russ]. 


\title{
COMPARISON OF 3D MODELS OF AN OBJECT PLACED IN TWO DIFFERENT MEDIA (AIR AND WATER) CREATED ON THE BASIS OF PHOTOS OBTAINED WITH A MOBILE PHONE CAMERA
}

\author{
P. Kujawa ${ }^{1 *}$ \\ ${ }^{I}$ Faculty of Geoengineering, Mining and Geology, Wroctaw University of Science and \\ Technology, Wybrzeże Wyspiańskiego 27, 50-370 Wroctaw, Poland
}

Keywords: mobile photogrammetry, underwater photogrammetry, digital close-range photogrammetry, mobile phone cameras, 3D reconstruction

The current technological progress has influenced the development of many technologies, including digital technology. This is especially noticeable with mobile phones. The most modern models have cameras with parameters equal to many professional digital SLRs. Low cost of purchase and maintenance, portability and high image quality of photos caused that mobile phones are increasingly used also by photogrammeters to create 3D models, inventory of architectural objects, etc. Waterproof is also an important advantage of smartphones, so they can be potentially used in underwater photogrammetry to assess the technical condition of objects under water.

This paper presents the photogrammetric capabilities of mobile phone cameras for inspecting objects located in two different media (in the air and under water). Two threedimensional models of the gear were made and compared.

\section{REFERENCES}

Balletti C., Beltrame C., Costa E., Guerra F., Vernier P., 2015. Underwater photogrammetry and 3D reconstruction of marble cargos shipwreck. The International Archives of the Photogrammetry, Remote Sensing and Spatial Information Sciences, Vol. 40 (5W5), 7-13.

Gruen A., Akca M. D., 2007. Mobile Photogrammetry. Dreiländertagung SGPBF, DGPF und OVG, Vol. 16, 441-451.

Menna F., Nocerino E., Troisi S., Remondino F., 2013. A photogrammetric approach to survey floating and semi-submerged objects. Videometrics, Range Imaging, and Applications XII; and Automated Visual Inspection, $87910 \mathrm{H}$.

Wojtkowska M., Kaczyński R., 2017. Quality assessment of underwater photogrammetric images for archeology purposes. Bulletin of the Military University of Technology, Vol. 66, No. 3, 27-44.

\footnotetext{
* Corresponding author: paulina.kujawa@pwr.edu.pl
} 
October 14-16, 2020

\title{
MESOSCALE CONVECTIVE SYSTEM AS A SOURCE OF ELECTROMAGNETIC SIGNALS REGISTERED BY GROUD-BASED SYSTEM AND DEMETER SATELLITE
}

\author{
K. Martyński ${ }^{1 *}$, J. Błęcki \\ ${ }^{I}$ Department of Electronics, AGH University of Science and Technology, Kraków, Poland \\ ${ }^{2}$ Space Research Centre PAS, Warsaw, Poland
}

Keywords: Thunderstorm, DEMETER, ELF, MCS

In recent years an intensified thunderstorm activity in Europe is observed, both for intensity of the discharges as well as for their number. Significant cloud formations are observed mostly during the summertime, where the advection of the warm maritime air is enriched by water vapor. In propitious atmospheric conditions, thus with significant convection, atmospheric instability and strong vertical thermal gradient, strong thunderstorm events are likely to occur. Mesoscale Convective System [Price et al., 2002] are significantly developed storms, which generate enormous amount of $+\mathrm{CG},-\mathrm{CG}$ and IC discharges. This presentation is focused on the measurements of the electromagnetic field in the ELF (Extremely Low Frequencies) range (3 to $30 \mathrm{~Hz}$ ), since they allow to compute charge moment of the impulses, which come from the source. Furthermore these impulses are observed by satellite as well. That allowed us to find correlations between ground-based and satellite measurements [Blecki et al., 2016]. Identification of a MCS is a complex process, due to a large number of variables such as cloud reflectivity, vertical thermal gradient or distribution of water vapor throughout troposphere. We took into account most measurements, which provide mentioned information, mostly be atmospheric soundings and detection of the impulses by PERUN system. On 23rd of July 2009 an event, which was identified as MCS has occurred and has been taken for further expertise.

The studies were conducted with financial help the National Science Centre, grant No. 2017/27/B/ST10/02285.

\section{REFERENCES}

Blecki J., Parrot, M., Słomiński, J., Kościesza, M., Wronowski, R., Savin, S., 2016, Evolution of the ionospheric Plasma Turbulence over Seismic and Thunderstorm Areas, Journal of Environ mental Science and Engineering, Vol. A6, pp. 277-285.

Price, C., M. Asfur, W. Lyons, and T. Nelson (2002), An improved ELFVLF method for globally geo locating sprite-producing lightning, Geophys. Res. Lett., 29(3), 1031, doi:10.1029/2001GL013519.

\footnotetext{
*Corresponding author: karol.martynski@agh.edu.pl
} 


\title{
UTILIZATION OF FIELD SEISMOMETERS FOR MEASURING THE PARASEISMIC VIBRATIONS OF MINING BLASTS
}

\author{
O. Molinek ${ }^{1 *}$, M. Vokurka ${ }^{1}$, A. Mokrosova ${ }^{1}$, J. Kotrbanec $^{1}$ \\ ${ }^{1}$ VSB - Technical University of Ostrava, 70800, Ostrava-Poruba, 17. listopadu, 2172/15, \\ Czech Republic
}

Keywords: BRS32; paraseismic; quarry; seismicity; seismometers; vibrations

This work entitled Utilization of field seismometers for measuring the paraseismic vibrations of mining blasts focuses mainly on the use of field seismometers for measuring large-scale blasting works in the Hrabůvka quarry operation. The first part describes the quarry itself, especially the geology and hydrogeology of the deposit. In the next part, the work focuses on a general description of the seismic threat, which is divided according to its origin into natural and artificially created seismicity. Consequently, its enshrining in Czech legislation is addressed. In the following chapter, the work deals with the description of the realization of measurements, which took place using two autonomous measuring devices BRS32, always for the most important objects in the quarry such as a workshop, weighing machine, primary shredder, office building, substation or sanitary facilities building. Last but not least, in this work, the seismographs of individual measurements are graphically represented with labels of where and when these values were measured. The final part of the article is a summary of measurement results and their evaluation.

\section{REFERENCES}

Cihal R 2017 Optimization of cargo and material loading in the Hrabuvka quarry. Ostrava. Master's thesis. VŠB - TUO Faculty of Mining and Geology. Thesis supervisor Martin Hummel.

Cerny P 2000 Plan for the opening, preparation and mining of an exclusive building stone deposit in Hrabuvka quarry. Internal documents of the company Ceskomoravsky sterk, a.s.

Cerny P 2014 Change (update) of the plan for the opening, preparation and mining of the exclusive building stone deposit in the Hrabůvka mining area. Internal documents of the company Ceskomoravsky sterk, a.s.

Broz M et al 2018 Seismicity in the area of western and northern Bohemia and a project to open the Goethe adit in the Komorni hurka volcano. 20/5000. Newsletter BROWN COAL., (2), 12.

Pravda V et al. 2010 Blasting work in mining, construction and speleology. Jesenice u Prahy: Montanika. ISBN 978-80-254-8542-2. CSN 73 0040: Loads acting on structures due to technical seismic activity and their response. 2nd ed. Prague, 2019.

\footnotetext{
* Corresponding author: oskar.molinek@vsb.cz
} 


\title{
STATISTICAL ANALYSIS OF SURFACE DEFORMATIONS CAUSED BY SEISMICITY INDUCED BY UNDERGROUND MINING
}

\author{
K. Owczarz ${ }^{1 *}$, J. Blachowski $^{1}$ \\ ${ }^{1}$ Wroclaw University of Science and Technology, Stanisława Wyspiańskiego 27 Street, 50- \\ 370 Wroctaw, Poland
}

Keywords: underground mining, induced tremors, DInSAR, GIS, surface displacements

Induced seismicity is one of the effects of industrial activity related to the exploitation of mineral resources. This seismic activity is directly or indirectly caused by industrial operations such as: mining, geothermal energy production, underground storage of liquids and gases, extraction of conventional and unconventional hydrocarbons, construction of dams and retention reservoirs. These technological processes change the stress distribution of the earth's crust may cause seismic shocks. In recent years, there has been a significant increase in interest in induced seismicity by the scientific community, industry, local government, as well as general society. The growing interest in this topic is due to the growing demand for energy and mineral resources.

The main goal of the research was the spatial analysis of the geometry of surface displacements caused by induced tremors in the Rudna copper mine (Poland) and the dependence of deformation characteristics (vertical displacements, extent) on the induced shock energy. During the research, vertical surface displacements were determined for 6 shocks induced using the DInSAR method and Sentinel-1 imagery. On the basis of the obtained displacement maps, pixel-to-pixel spatial analyzes were performed in the GIS environment. The average values of vertical displacements ranged from $-67 \mathrm{~mm}$ to -119 $\mathrm{mm}$. GIS analyzes revealed a strong statistical correlation $(\mathrm{R} 2>0.70)$ between the mean vertical displacements, the mean spatial ranges of the troughs (size) and the shock energy. The research results showed that the cause of surface deformation is not only induced tremors, but also underground mining. The obtained results will be used to develop the knowledge base on surface displacements caused by tremors induced in the underground copper mine.

\footnotetext{
*Corresponding author: karolina.owczarz@pwr.edu.pl
} 


\title{
METHODOLOGY FOR CALCULATE BEARING CAPACITY OF SOFT SOILS UNDER CYCLIC LOADING
}

\author{
D. R. Panique Lazcano ${ }^{1 *}$, R. A. Galindo Aires ${ }^{1}$, C. Olalla Marañon ${ }^{1}$ \\ ${ }^{1}$ Departamento de Ingeniería del Terreno (Universidad Politécnica de Madrid, c/Profesor \\ Aranguren s/n, Madrid 28040, Spain)
}

Keywords: Bearing capacity, soft soils, cyclic load, cyclic softening, pore-water pressure generation

The bearing capacity in soft soils under cyclic loading has not been widely studied over time as the static bearing capacity. Detailed studies began as a consequence of the Northridge, Kocaeli and Chi-Chi earthquakes that occurred in the 1990s, where the phenomenon of cyclic softening was evidenced and many structures suffered severe damage as a consequence of this phenoemenon. The purpose of this work was propose a methodology for calculate of bearing capacity in soft soils under cyclic loading. The research based in the results of monotonic and cyclic simple shear tests carried out with samples from the PRAT port in Barcelona. From an analysis carried out on all the experimental data, a pore-water pressure generation equation is proposed that depends on the effective vertical stress "in situ" $\left(\sigma_{v o}^{\prime}\right)$, initial shear stress $\left(\tau_{0}\right)$, cyclic shear stress $\left(\tau_{c}\right)$ and void ratio $(e)$. The formulation was implemented in the FLAC2D finite difference software, and a methodology of the calculation process is proposed. The methodology consists of 6 calculation stages, the first one consists of the creation of the mesh, designation of soil and water properties, selft-weight and contour conditions of the model. The second stage corresponds to the determination of the permanent load (PL) on the footing and the effective load outside the foundation $(q)$. The third stage is the assignment of the cyclic load $(C L)$ on the footing. The fourth stage corresponds to the calculation of the pore-water pressure generation by means of the proposed formulation. The fifth stage corresponds to the calculation of the equilibrium state of stresses. The sixth stage is the calculation of the bearing capacity of the soil. Then a verification is made under two criteria, the first verifies that the bearing capacity is zero or close to zero, and the second verifies that the MohrCoulomb failure criterion is met. If any of the two criteria is not met, it is necessary to go back to thirth stage and change the value of the cyclic load to a higher or lower value as appropriate to carry out the calculations again. This process is iterative until the maximum value of cyclic load on the footing is found that can resist. Under this methodology of the calculation process, charts are proposed for calculate the bearing capacity of soft soils under cyclical load (CL). This application takes into account soil properties, static bearing capacity (Phe) and effective load outside the foundation (q). In addition, an analysis of the

\footnotetext{
*Corresponding author: dr.panique@alumnos.upm.es
} 


\section{Book of abstracts \\ XX Conference of PhD Students and Young Scientists \\ October 14-16, 2020}

parameters that most influence the bearing capacity of soft soils under cyclic loading was carried out. 


\title{
USE OF ABCD-MATRIX METHOD FOR THE SIMULATION OF LASER- ULTRASONIC PROBING PULSE PROPAGATION A IN A LAYERED MEDIUM OF THE OPTICAL-ACOUSTIC TRANSDUCER
}

\author{
A. I. Pashkin ${ }^{1 *}$ \\ ${ }^{\text {I} N U S T ~ « M I S i S » ~ L e n i n s k y ~ p r o s p e c t, ~ 4, ~ 119049, ~ M o s c o w, ~ R u s s i a n ~ F e d e r a t i o n ~}$
}

Keywords: laser opto-acoustics, ultrasonic control, layered media, flow defectoscopy, modeling methods, $\mathrm{ABCD}$ matrix, structuroscopy, propagation of the acoustic pulse.

As a first step methods for modeling the propagation of acoustic waves in layered media was analyzed and the need to develop a new, faster method is substantiated (Mottershead J.E. and Friswell M.I., 1993; Friswell M.I. and Mottershead J.E., 1995; Zou Y. et al., 2000; Sinha J.K. et al., 2002; Liu G.R. and Han X., 2003; Taheri H. et al., 2017; Sun H. et al.,2016; Gravenkamp H. et al., 2017; Jung J. et al., 2013). As a consequence, presented a method for modeling the propagation of elastic waves based on signal transformation using ABCD matrices, for the implementation of which a computer program in the Python language has been developed. For the verification of the method was analyzed the correlation between the simulated signal and the signal obtained experimentally from a medium with predetermined parameters. Further on the basis of the data obtained, the applicability of this method for modeling the propagation of acoustic signals in a plane-layered medium has been proved. As a next step modern methods of ultrasound generation and their influence on the characteristics of the probing signal was reviewed (Tschegg E.K. et al., 2015; Ahn S. et al., 2016; Chen J.G. et al., 2015;Castellano A. et al., 2017; Dong et al., 2015; Bychkov A. S., 2016). Confirmed that laser-ultrasound techniques allow the best control over the characteristics of the probe signal. Therefore, the influence of the duration of the laser pulse, the properties of light absorption and the acoustic characteristics of the generator medium on the probing signal amplitude and bandwidth of the spectrum was estimated. To reduce the influence of the considered characteristics on the diagnostic process using the ABCDmatrix method the optimal characteristics of the optical-acoustic transducer for diagnostics at low frequencies have been determined. Finally, the main advantage of the proposed modeling method is the high speed of calculating the shape and spectrum of the signal at any point in the medium at a given time.

Acknowledgments: The reported study was funded by RFBR, project number 20-3590044

\footnotetext{
*Corresponding author: Alexandrill@ya.ru
} 


\section{Book of abstracts \\ XX Conference of PhD Students and Young Scientists \\ October 14-16, 2020}

\section{REFERENCES}

Mottershead J.E., Friswell M.I., Model updating in structural dynamics: a survey // J. Sound Vib., 1993, v. 167, pp. $347-375$

Friswell M.I., Mottershead J.E. Finite Element Model Updating in Structural Dynamics. Kluwer Academic Publishers, Dordrecht, The Netherlands. 1995. 286 p.

Zou Y., Tong L., Steven G.P. Vibration-based model-dependent damage (delamination) identification and health monitoring for composite structures-a review // J. Sound Vib., 2000, v .230, pp. 357-378

Sinha J.K., Friswell M.I., Edqards S. Simplified models for the location of cracks in beam structures using measured vibration data // J. Sound Vib., 2002, v. 251, pp. 13-38

Liu G.R., Han X. Computational Inverse Techniques in Nondestructive Evaluation. CRC Press, Boca Raton, FL. 2003. 592 p.

Taheri H., Koester L. W., Bigelow T. A., Bond L. J. Thermoelastic finite element modeling of laser generated ultrasound in additive manufacturing materials. // ASNT Annual Conference 2017. — 2017. - P. 188-198

Sun H., Waisman H., Betti R. A sweeping window method for detection of flaws using an explicit dynamic XFEM and absorbing boundary layers // Internat. J. Numer. Methods Engrg., 2016, v. 105, pp. 1014-1040

Gravenkamp H., Natarajan S., Dornisch W., On the use of NURBS-based discretizations in the scaled boundary finite element method for wave propagation problems // Comput. Methods Appl. Mech. Engrg., 2017, v. 315, pp. 867-880

Jung J., Jeong C., Taciroglu E. Identification of a scatterer embedded in elastic heterogeneous media using dynamic XFEM // Comput. Methods Appl. Mech. Engrg., 2013, v. 259, pp. 50-63

Tschegg E.K., Schneemayer A., Merta I., Rieder K.A. Energy dissipation capacity of fibre reinforced concrete under biaxial tension compression load. Part II: Determination of the fracture process zone with the acoustic emission technique. // Cement and Concrete Composites, 2015, v. 62, pp. 187-194

Ahn S., Jeon E.B., Koh H., Kim S., Park J. Identification of stiffness distribution of fatigue loaded pol-ymer concrete through vibration measurements. // Composite Structures, 2016, v. 136, pp. 11-15

Chen J.G., Haupt R.W., Buyukozturk O. Operational and defect parameters concerning the acoustic-laser vibrometry method for FRP-reinforced concrete. // NDT \& E International, 2015, v. 71, pp. 43-53

Castellano A., Fraddosio A., Piccioni M. D. Ultrasonic goniometric immersion tests for the characterization of fatigue post-LVI damage induced anisotropy superimposed to the constitutive anisotropy of polymer composites. // Composites Part B: Engineering, 2017, v. 116, pp. 122-136

Dong J., Kim B., Locquet A., McKeon P., Citrin D.S. Nondestructive evaluation of forced delamination in glass fiber-reinforced composites by terahertz and ultrasonic waves. // Composites Part B: Engineering, 2015, v. 79, pp. 667-675

Bychkov A.S., Cherepetskaya E.B., Karabutov A.A., Makarov V.A., Laser optoacoustic tomography for the study of femtosecond laser filaments in air // Laser Physics Letters, 2016, v. 13, i. 8, № 085401 


\title{
APPLICATION OF HIGH- AND LOW-PASS SPATIAL FILTERS IN ANALYSIS OF CONE PENETRATION TEST (CPTU)
}

\author{
J. Rainer ${ }^{1 *}$, I. Bagińska ${ }^{2}$ \\ ${ }^{1}$ Wrocław University of Science and Technology, Faculty of Civil Engineering, \\ Wyb. Wyspiańskiego 27, 50-370 Wroctaw, Poland
}

Keywords: Cone Penetration Test (CPTu), Convolutional Filter, High-Pass Spatial Filter, Low-Pass Spatial Filter

The paper discusses the use of low- and high- pass spatial filters to interpret recordings obtained during the Cone Penetration Tests (CPTu). These filters are widely used in digital signal processing. A inverse low-pass filtration procedure is described, which is used to reduce the effects associated with the stratified subsoil, i.e. thin layer effect and transition zone. The procedure of high-pass filtering is also presented, allowing to locate probable places where a boundary of layers occurs. Both of the above mentioned methods were tested on natural and anthropogenic dumping soils in order to present the principle of operation, as well as to show their usefulness and effectiveness in interpretation of $\mathrm{CPTu}$ measurements.

\section{REFERENCES}

Lunne T. Robertson P. Powell J. Cone Penetration Testing in Geotechnical Practice, New York, Spon Press Taylor\&Francis Group, 1997

Lim Yi Xian, Numerical study of cone penetration test in clays using press-replace method, National University of Singapore, Chiny, 2017

Mayne, P. W. (2001, May). Stress-strain-strength-flow parameters from enhanced in-situ tests. In Proc. Int. Conf. on In Situ Measurement of Soil Properties and Case Histories, Bali (pp. 27-47).

Bałachowski, L. (2006). Soft soil overconsolidation and CPTU dissipation test. Archives of Hydro-Engineering and Environmental Mechanics, 53(2), 155-180.

Boulanger R.W. DeJong J.T. (2018), Inverse filtering procedure to correct cone penetration data for thin-layer and transition effects Cone penetration testing 2018: proceedings of the 4th International Symposium on Cone Penetration Testing (CPT'18), Delft, The Netherlands, 21-22 June 2018 / eds. Michael A. Hicks, Federico Pisanò, Joek Peuchen. Leiden: CRC Press/Balkema.

Li, X. Y., Zhang, L. M., Zhu, H., \& Li, J. H. (2018). Modeling geologic profiles incorporating interlayer and intralayer variabilities. Journal of Geotechnical and Geoenvironmental Engineering, 144(8), 04018047.

Rainer J., Szabowicz H. (2020). Analysis of underground stratification based on CPTu profiles using high-pass spatial filter, Studia Geotechnica et Mechanica (Preprint), 3

Chwała, M. (2019). Undrained bearing capacity of spatially random soil for rectangular footings. Soils and Foundations, 59(5), 1508-1521.

Baca, M., Brząkała, W., \& Rybak, J. (2020). Bi-Directional Static Load Tests of Pile Models. Applied Sciences, 10(16), 5492.

\footnotetext{
* Corresponding author: jakub.rainer@pwr.edu.pl
} 


\section{Book of abstracts \\ XX Conference of PhD Students and Young Scientists \\ October 14-16, 2020}

Ching, J., Wu, T. J., Stuedlein, A. W., \& Bong, T. Estimating horizontal scale of fluctuation with limited CPT soundings. Geoscience Frontiers, 9(6), 2018, 1597-1608,2018

Cristobal G., Schelkens P. Thienpont H., Optical and digital image processing: Fundamentals and applications Wiley-VCH Verlag GmbH\&Co, 2011

Puła, W., Bagińska, I., Kawa, M., \& Pieczyńska-Kozłowska, J. (2017). Estimation of spatial variability of soil properties using CPTU results: a case study. In-situ and laboratory characterization of OC subsoil. Exemplum, Poznań, 23-32.

Bagińska I. Kawa M. Janecki W., Estimation of spatial variability of lignite mine dumping ground soil properties using CPTu results, Studia Geotechnica et Mechanica, 2016, vol. 38, nr 1, s. 3- 13

Bagińska I. Kawa M. Janecki W., Estimation of spatial variability properties of mine waste dump using CPTu results- case study Cone penetration testing 2018 : proceedings of the 4th International Symposium on Cone Penetration Testing (CPT'18), Delft, The Netherlands, 21-22 June 2018 / eds. Michael A. Hicks, Federico Pisanò, Joek Peuchen. Leiden: CRC Press/Balkema, 2018 


\title{
THE USE OF MAN-MADE WASTE, THE VECTOR OF GREEN GEOTECHNOLOGY DEVELOPMENT
}

\author{
A. Sharova ${ }^{1 *}$, V. Faradzhov ${ }^{1}$, M. Khayrutdinov ${ }^{1}$, A. Kopylov ${ }^{2}$ \\ ${ }^{I}$ National University of Science and Technology MISiS, 119049, Moscow, \\ Leninskiy prospekt 4, Russia \\ ${ }^{2}$ North Caucasian Institute of Mining and Metallurgy (State Technological University), \\ 362021, Vladikavkaz, Nikolaev street 44, Russia
}

Keywords: geotechnology, backfill, mining and processing waste, ecology

The problems caused by the activities of enterprises for the extraction and processing of solid minerals affect the technological, economic and environmental spheres. With an increase in the extraction of mineral resources the volumes of accumulated man-made waste. Geotechnogenic human impacts on the environment are increasing every year (Khayrutdinov, 2009).

Therefore, when choosing methods and systems for field development, it is necessary to consider not only the technical and economic indicators of production, but also the impact of mining operations on the environment.

The developed mineral deposits are objectively a source of environmental pollution. A great potential threat to the environment is posed by man-made wastes.

The solution to this problem can be carried out by applying the technology with backfilling of the goaf. This method has a number of advantages, such as the ability to control rock pressure and improve safety in mining operations; improving the quality of recovered ores, which will increase the recovery factor and increase the life of the mine (Khayrutdinov, 2007).

The approach of placing waste from the mining and processing industry in underground mines and cavities can reduce the harmful impact of production on the environment and creates favorable conditions for the introduction of waste-free technologies (Golik et al., 2012).

The use of man-made wastes will reduce the cost of stowing work, the maintenance of dumps and tailings, the construction of special quarries for the extraction of inert aggregate and transportation costs, thus reducing the cost of the process and achieving economic effect. The method of using mining waste for backfill is promising, since a number of economic and environmental problems are being solved (Khayrutdinov, 2007).

In order to take into account the totality of all forms of impact of geotechnology on the natural environment and related human activities in the process of mining and improve measures for the rational use of natural resources, it is necessary to purposefully change the technologies used.

* Corresponding author: sharova@edu.misis.ru 


\section{Book of abstracts \\ $\mathrm{XX}$ Conference of PhD Students and Young Scientists \\ October 14-16, 2020}

The effectiveness of the application of technologies for the rational extraction of minerals is determined by the ratio of costs and damage from waste storage, and the area of effective use of environmental technologies is determined as a set of values that correspond to the acceptable quality of the environment with affordable costs for its maintenance (Figure 1).

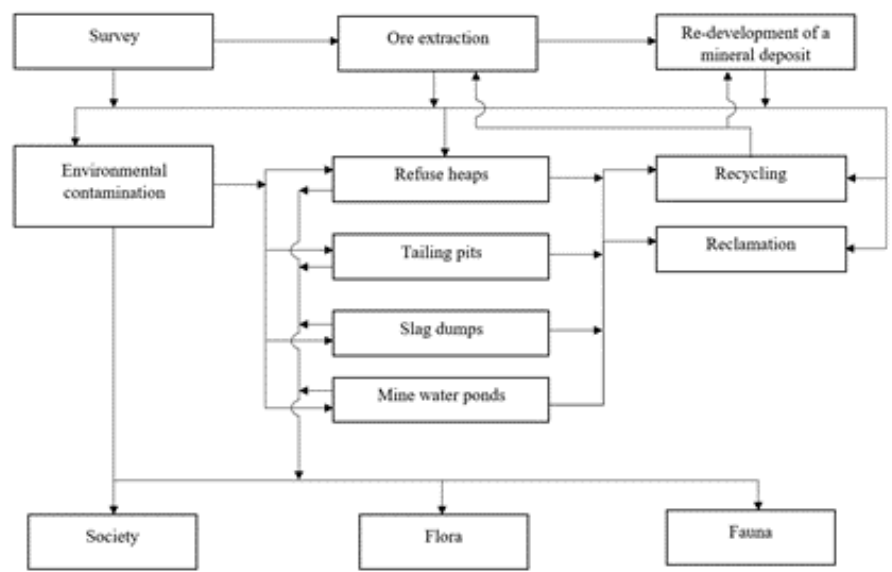

Figure 1. Scheme of the impact of mining on the ecosystem.

To improve measures for the rational use of natural resources, it is necessary to fully work out the concepts of planned management and develop a mathematical model of the impact of geotechnology on the environment.

The use of a cyclical organization of production, which excludes the generation of waste and predetermines their use as intermediate products in closed production and in the creation of products for other industries, is the main direction of development (Figure 2). 


\section{Book of abstracts \\ $\mathrm{XX}$ Conference of PhD Students and Young Scientists \\ October 14-16, 2020}

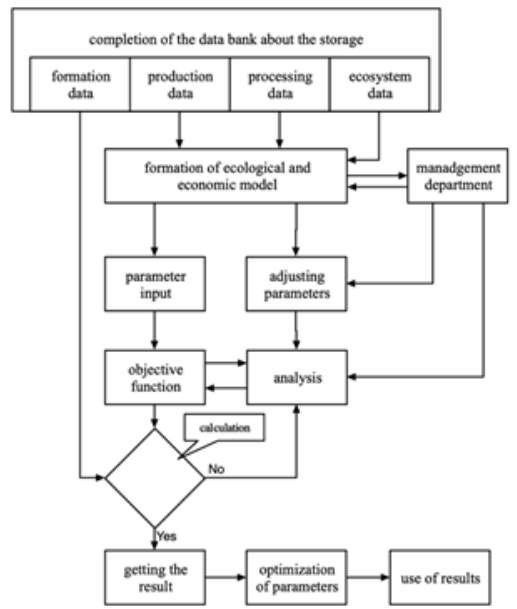

Figure 2. Algorithm for calculating the efficiency of applying technologies for the rational extraction of minerals.

The technology of sustainable development and rational extraction of minerals implies the transition from measures of an exclusively protective nature to the planned management of natural resources and the use of waste-free geotechnology, using materials from manmade waste. Sustainable development excludes the generation of waste and involves the use of intermediate products in a closed cycle of the main or auxiliary production.

\section{REFERENCES}

Golik V.I., Komashchenko V.I., Stradanchenko S.G., Maslennikov S.A., 2012. Increasing the completeness of subsurface usage by the deep recycling of coal concentration. Gornyi Zhurnal, No. 9, 91-95.

Khairutdinov M.M., 2007. Ways to improve development systems with backfill. Gornyi Zhurnal, No. 11, 40-43. Khayrutdinov M.M., 2009. The use of mining waste as a backfill material to reduce the harmful impact on the environment. Gornyi Zhurnal, No. 2, 64-66. 


\title{
EPIGENETIC AND INDUCED FRACTURES FROM THE RADKÓW BLUFF (STOLOWE MOUNTAINS) DOCUMENTED WITH TERRESTRIAL LASER SCANNER - STRUCTURAL IMPLICATIONS
}

\author{
D. Sokalski ${ }^{12^{*}}$, J. Wojewoda $^{1}$, A. Kowalski ${ }^{1}$ \\ ${ }^{I}$ Wroclaw University, Institute of Geological Sciences, 9 Maksa Borna, 50-204 Wroclaw, \\ Poland \\ ${ }^{2}$ KGHM Polska Miedź S.A., 48 Marii Skłodowskiej-Curie, 59-301 Lubin, Poland
}

Keywords: terrestrial laser scanner, induced fractures, epigenetic fractures, Stołowe Mountains

The type of specific induced fractures was first described on some granite boulders from several locations in eastern Australia (Ollier, 1978). At the base of these rock forms fractures of a non-tectonic origin develop, i.e. not related to the regional structural plan of the area. These fractures are the result of local, gravitationally induced rock mass to failure at its base.

Fractures of this type are relatively common and can be observed worldwide, both in natural and artificial sites. In Poland, they were described for the first time in the Stołowe Mountains, in the rocks occurring within the so-called Radków Bluff (Wojewoda, 2012). This morphological form, unique on the European scale, which together with the Broumovské Steny and Mieroszowskie Walls, forms a $30 \mathrm{~km}$ long and even $300 \mathrm{~m}$ high morphological escarpment, built of Cretaceous sandstone.

Within the Radkow Bluff, at the base of some individual rock forms, these gravityinduced epigenetic (sensu Wojewoda) fractures develop. Structural analysis carried out in several outcrops in the site between the Stroczy Zakręt and the Psi Potok valley revealed fracture sets with the general orientation imposed by the shape of individual rock forms. These extensional fractures often demonstrate their non-planar character, which is manifested by the characteristic torsion of the fracture surface along predisposed helicoidal surfaces.

The authors present an innovative way of documenting structural phenomena with the use of a terrestrial laser scanner, which is a valuable supplement to traditional measurement methods using a geological compass. It also allows to measure structures in places that are difficult or even inaccessible to manual measurement. Additionally, this method allows for recording the propagation of damage occurring in time on a scale of a single outcrop. In this respect, it is successfully used to register and analyse analogous damage in the Rudna underground copper mine, located near the town of Polkowice in Lower Silesia (Sokalski et al., 2019).

\footnotetext{
* Corresponding author: Dominik.Sokalski@kghm.com
} 


\section{Book of abstracts \\ $\mathrm{XX}$ Conference of PhD Students and Young Scientists \\ October 14-16, 2020}

Observations, measurements and analyses carried out by the authors allow to conclude that epigenetic fractures occurring at the base of the examined rock forms constitute privileged zones from which the process of degradation and destruction of the sandstone scarp begins.

\section{REFERENCES}

Ollier C., 1978. Induced fractures and granite landforms, Zeitschrift für Geomorphologie 22 (3), p. $249-257$.

Sokalski D., Wojewoda J., Kasza D., Wajs J., 2019. Tectonic Structures Related to Paulinów Syncline in Rudna Copper Mine, Poland Documented with Terrestrial Laser Scanner. [In:] 20th Czech-Polish Workshop on Recent Geodynamics of Central Europe, 24-26 of October 2019, Szklarska Poręba, Poland, p. 40.

Wojewoda, J., 2012. Joints in Cretaceous sandstones of the Góry Stołowe Mountains: tectonic and non-tectonic.

[In:] 13th Czech - Polish Workshop On Recent Geodynamics of the Sudety Mts. and Adjacent Areas,

November 20 - 22, Wrocław-Pawłowice, Poland, p. 57-58. 


\title{
PRELIMINARY RESEARCH TO DETERMINE THE THERMAL CONDITION OF THE BELT CONVEYOR'S DRIVE UNIT IN AN UNDERGROUND HARD COAL MINE
}

\author{
M. Stempniak ${ }^{1}$, V. Zhironkin ${ }^{2}$, K. Trzop ${ }^{3}$, D. Szurgacz ${ }^{4 *}$

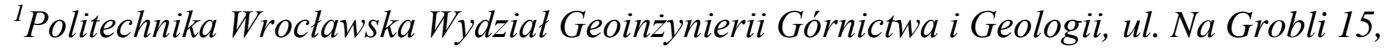 \\ 50-421Wroctaw, Poland \\ ${ }^{2}$ National Research Tomsk Polytechnic University, 28 Vesennya st., 634034 Tomsk, Russia \\ ${ }^{3}$ KWK Ruda Ruch Bielszowice ul. Halembska 160, 41-711 Ruda Ślaska, Poland \\ ${ }^{4}$ KWK ROW Ruch Chwatowice, ul. Przewozowa 4, 44-206 Rybnik, Poland
}

Keywords: belt conveyors, thermovision, thermal condition, underground mine, work safety.

The paper presents preliminary research conducted to determine the thermal condition of the main belt conveyor transporting coal from the longwall. The results show the thermal condition of the conveyor and in the further stage are used to effectively diagnose possible causes of damage to the belt conveyor's drive unit. The tests were performed on the conveyor whose operation is strategic to the mine. The research comprised a thermal imaging camera that allows taking contact-free measurements. The main purpose of a thermal imaging measurement is to detect changes in thermal conditions without the need to stop the conveyor belt. The paper presents the methodology and discusses the manner of performing underground measurements as well as a procedure for processing the results. The final conclusions concerning the technical condition of the drive unit were based on the results and their analysis.

\section{REFERENCES}

Sawicki M, Stefaniak P, Zimroz R, Błażej R, Król R 2014 Wykorzystanie metod termowizyjnych do badania stanu technicznego układów napędowych przenośników taśmowych w O/ZG Polkowice-Sieroszowice, Interdyscyplinarne zagadnienia w górnictwie i geologii, Tom V, pod red. Drzymały J., Wrocław, s. 177183.

Stefaniak P, Błażej R, Jurdziak L, Sawicki M, Zimroz R, Hardygóra M 2013 Metody badań stanu technicznego i pracy elementów przenośnika taśmowego, Problemy bezpieczeństwa w budowie i eksploatacji maszyn i urządzeń górnictwa podziemnego: monografia pod red. Krzysztof Krauze, Centrum Badań i Dozoru Górnictwa Podziemnego, Ledziny, s. 213-223.

Błażej R, Bajda M, Hardygóra M 2017 Monitoring creep and stress relaxation in splices on multiply textile rubber conveyor belts, Acta Monta. Slo. Volume 22(2) p. 116-125.

Gładysiewicz L, Król R, Kisielewski W, Kaszuba D 2017 Experimental determination of belt conveyors artificial friction coefficient, Acta Monta. Slo. Volume 22(2) p. 206-214.

Szolc P, Stempniak M, Grudziecki R, Pałka D 2020 A Survey on the potential of monitoring of longwall complex parameters based on industry 4.0., E3S Web Conf. Volume 174, (01065).

\footnotetext{
* Corresponding author: dawidszurgacz@vp.pl
} 


\author{
Book of abstracts \\ XX Conference of PhD Students and Young Scientists \\ October 14-16, 2020
}

\title{
SPECIFIC ENERGY CONSUMPTION OF BELT CONVEYORS - K- MEANS CLUSTERING
}

\author{
N. Suchorab ${ }^{1 *}$, R. Król ${ }^{1}$ \\ ${ }^{1}$ Faculty of Geoengineering, Mining and Geology, Wroctaw University of Science and \\ Technology, Wybrzeże Stanistawa Wyspiańskiego 27, 50-370 Wrocław, Poland
}

Keywords: belt conveyor, specific energy consumption, k-means clustering

The entire mining industry faces challenges of Sustainable Development requirements among which energy-efficient and eco-friendly transportation systems are very important (Soofastaei et al., 2018). Because of that, the Specific Energy Consumption (SEC) index has been proposed to assess the performance of belt conveying systems taking into consideration their working conditions. Based on index value it is possible to create specific groups of belt conveyors which labels reflect their energy and environmental aspect (Kawalec and Król, 2019).

In this research, data for conveyors in continuous surface mine was analyzed. Data involved the capacity of transported material, conveyors ' electric energy consumption, and their technical parameters such as length and inclination angle. Results show SEC value distribution within the whole year for downhill, horizontal, and uphill conveyor. Eventually, the initial work on grouping belt conveyors by SEC value with the use of K-means clustering was presented.

\section{REFERENCES}

Soofastaei, A.; Karimpour, E.; Knights, P.; Kizil, M. Energy-efficient loading and hauling operations. In Green Energy and Technology; Springer Verlag, 2018; pp. 121-146.

Kawalec, W., Król, R., 2019. Sustainable Development Oriented Belt Conveyors Quality Standards, in: Rusiński, E., Pietrusiak, D. (Eds.), Proceedings of the 14th International Scientific Conference.Computer Aided Engineering, Lecture Notes in Mechanical Engineering TS - CrossRef. Springer, Cham, Switzerland, pp. 327-336

\footnotetext{
*Corresponding author: natalia.suchorab@pwr.edu.pl
} 


\title{
FAILURE ANALYSIS OF ELEMENTS OF STORAGE BUNKERS USED IN KGHM RUDNA COPPER MINE
}

\author{
M. Szczerbakowicz ${ }^{12^{*}}$, N. Suchorab ${ }^{2}$, R. Król ${ }^{2}$ \\ ${ }^{1}$ KGHM Polska Miedź S.A. Oddziat Zaktady Górnicze ,Rudna”ul. Henryka \\ Dąbrowskiego 50, 59-100 Polkowice \\ ${ }^{2}$ Faculty of Geoengineering, Mining and Geology, Wroctaw University of Science and \\ Technology, Wybrzeże Stanistawa Wyspiańskiego 27, 50-370 Wroctaw, Poland
}

Keywords: storage bunker, failure analysis, copper mine

In Polish Rudna copper mine, there are two crucial points for which receiving bins are widely used, namely departmental islands (grate) and storage bunkers. Receiving bins and reciprocating plate feeders are crucial for a continuous belt conveyor transportation system. Although the receiving bin construction has been changed over the years, the working rules remain the same. Taking into account that receiving bin construction is not adjusted to specific working conditions in different parts of the mine, many problems during operation occur. Most of them are connected with wear damage of steel liner of receiving bin and reciprocating plate feeder as well as their construction durability. Different physicomechanical properties of copper ore have been recognized as the most significant reasons for the abrasive type of wear. Furthermore, different amount of transferred material via gate and storage bunker, which have the same construction, is a key factor in receiving bin and reciprocating plate feeder construction damages. Therefore, in the article authors present the analysis of collected examples of typical receiving bins and reciprocating plate feeders damages of in Polish copper mine.

\footnotetext{
*Corresponding author: mateusz.szczerbakowicz@pwr.edu.pl
} 


\title{
ASSESSMENT OF HUMAN IMPACT ON RIVERS AND GROUNDWATER QUALITY WITH THE USE OF ANTIBIOTIC RESIDUES ANALYSIS
}

\author{
K. Ślósarczyk ${ }^{1 *}$ \\ ${ }^{1}$ University of Silesia, Faculty of Natural Sciences, Institute of Earth Sciences
}

Keywords: antibiotics, pharmaceutical residues, emerging contaminants, rivers, groundwater quality

In recent years, advanced analytical methods have been developed which allow to detect various micropollutants in water. It concerns also emerging contaminants that usually occur in very small quantities in the natural environment. In this group, antibiotics and other pharmaceuticals are included (Lapworth et al., 2012). The increase in medicines consumption all over the world leads to greater loads of microcontamintants that are introduced to the water environment along with sewage discharges. In case of antibiotics, the problem of water contaminations is of particular significance due to negative consequences connected with pharmaceuticals occurrence in the environment. The example is the emergence of antibiotic resistance in certain bacteria species. It entails lower effectiveness of medicines in the future (Baquero et al. 2008). Moreover, pharmaceuticals residues present in water also affect other living organisms and even humans, since such contaminants may occur in drinking water (Caban et al., 2015).

In the research, there was an attempt to assess the human impact on surface water and groundwater quality using determination of antibiotic residues in water samples. In the analysis, 13 antibiotics were taken into account: erythromycin, sulfamethoxazole, penicillin G, sulfamerazine, sulfamethazine, sulfapyridine, trimethoprim, chloramphenicol, sulfanilamide, clarithromycin, roxithromycin, azithromycin and clindamycin. The analysis was performed using the liquid chromatography tandem mass spectrometry method (LCMS/MS). Concentrations and migration of antibiotics were studied in surface water (rivers) and groundwater within five areas located in Southern Poland, including two well-fields based on riverbank filtration. During fieldworks, 7 samples of surface water and 5 samples of groundwater were collected. Additionally, sewage samples from Wastewater Treatment Plants (WWTPs) were also gathered in order to assess the removal effectiveness for antibiotics. Since the watercourses were recipients of sewage discharges from WWTPs that usually do not manage to remove pharmaceuticals completely, the contamination of surface water with antibiotics was highly probable. The studied rivers were losing streams, therefore compounds could also migrate to aquifers.

The obtained results revealed low effectiveness of antibiotics removal from sewage for 8 out of 13 studied compounds. The most abundant antibiotics were clarithromycin (up to

*Corresponding author: kinga.slosarczyk@us.edu.pl 


\section{Book of abstracts \\ $\mathrm{XX}$ Conference of PhD Students and Young Scientists \\ October 14-16, 2020}

$5070 \mathrm{ng} / \mathrm{L}$ in untreated sewage and up to $600 \mathrm{ng} / \mathrm{L}$ in treated sewage), sulfamethoxazole (2 $300 \mathrm{ng} / \mathrm{L}$ and $1650 \mathrm{ng} / \mathrm{L}$ ) and azithromycin (1 $740 \mathrm{ng} / \mathrm{L}$ and $1160 \mathrm{ng} / \mathrm{L})$. Since antibiotics were still present in sewage after treatment processes, they entered the surface water. In sampled rivers, concentrations of studied pharmaceuticals ranged from $<10 \mathrm{ng} / \mathrm{L}$ to $1520 \mathrm{ng} / \mathrm{L}$. The highest values were observed for the same compound as in sewage. Up to 7 antibiotics were detected in rivers in concentrations above the limit of quantification. In case of studied aquifers, only 1 compound per each sample was observed. Among antibiotics, sulfanilamide and sulfamethoxazole were detected in groundwater, in concentrations up to $64.4 \mathrm{ng} / \mathrm{L}$ and $12.4 \mathrm{ng} / \mathrm{L}$, respectively. Interestingly, sulfanilamide was observed in groundwater, but it did not occur in rivers that flow in the vicinity of sampled wells. Therefore, within the studied areas another source of pollution with antibiotics cannot be excluded.

\section{REFERENCES}

Baquero F., Martinez J.L., Canton R., 2008. Antibiotics and antibiotic resistance in water environments. Current Opinion in Biotechnology, Vol. 19, 260-265.

Caban M, Lis E, Kumirska J, Stepnowski P., 2015. Determination of pharmaceutical residues in drinking water in Poland using a new SPE-GC-MS(SIM) method based on Speedisk extraction disks and DIMETRIS derivatization. Science of the Total Environment, Vol. 538: 402-411.

Lapworth D.J, Baran N., Stuart M.E., Ward R.S., 2012. Emerging organic contaminants in groundwater: A review of sources, fate and occurrence. Environmental Pollution, Vol. 163, 287-303. 


\title{
DEVELOPMENT OF A BUILDING TOPOLOGICAL MODEL FOR INDOOR NAVIGATION
}

\author{
P. Trybała ${ }^{*}$, A. Gattner ${ }^{1}$ \\ ${ }^{I}$ Faculty of Geoengineering, Mining and Geology, Wrocław University of Science and \\ Technology, Na Grobli 15, 50-421 Wroclaw, Poland
}

Keywords: indoor navigation, building modeling, route planning

Human high mobility is essential to the proper functioning of a modern world. For a fast and efficient ground transportation, a suitable and accessible positioning, route finding and navigation solutions are crucial. For outdoor traveling, mobile applications utilizing GNSS systems and navigation services based on road and pavement networks already provide a satisfying solution. On contrary, an indoor environment is much more intricate. Localization with GNSS is impossible and there is no explicit traversable network inside the building as in outdoor routes. Multi-storey buildings, often with complicated room layouts and floor transitions, confined spaces and numerous areas restricted for visitors or impassable pathways for disabled people add another layers of complexity to this problem. This study covers the issue of creating a topological building model for indoor navigation. Necessities of such a model are discussed and the fitting implementation, developed by ESRI, is detailed. The entire process, from data pre-processing to the model creation and visualization in ArcGIS Pro software, is delineated. A case study of development of such a model for a Geo-3EM building of Wrocław University of Science and Technology (WUST) is conducted and the sample visualizations of a model and route finding are shown. Finally, the results are discussed, and the future directions of research are presented.

\footnotetext{
*Corresponding author: pawel.trybala@pwr.edu.pl
} 


\title{
PREVENTIVE MEASURES TO MINIMIZE NATURAL HAZARDS IN THE POLISH UNDERGROUND MINING INDUSTRY
}

\author{
K. Trzop ${ }^{1}$, D. Palka ${ }^{2}$, D. Szurgacz ${ }^{3 *}$ L. Sobik ${ }^{4}$ \\ ${ }^{1}$ KWK Ruda Ruch Bielszowice ul. Halembska 160, $41-711$ Ruda Ślaska, Poland \\ ${ }^{2}$ Politechnika Śląska Wydziat Organizacji i Zarządzania, ul. Roosevelta 26-28, \\ 41-800 Zabrze, Poland \\ ${ }^{3}$ Polska Grupa Górnicza S.A., ul. Powstańców 30, 40-039 Katowice, Poland \\ ${ }^{4}$ KWK ROW Ruch Chwatowice, ul. Przewozowa 4, 44-206 Rybnik, Poland
}

Keywords: natural hazards, underground mining, hard coal, work safety, efficiency.

The process of underground hard coal mining and various types of natural hazards are inextricably bound up with each other. The occurrence depends on the response of the rock mass to the disturbance of its balance caused by mining activity determines the occurrence of natural hazards that can lead to a series of events that significantly disturb the safety and efficiency of the entire coal production process. Consequently, there is a constant search for methods that would support the available preventive measures. There are several solutions that can be applied during the mining process designed to either limit the frequency of hazards and/or limit their consequences. The paper reviews the current natural hazards in underground mining with particular emphasis on their consequences. Based on the experience of the authors and the review of papers that deal with natural hazards, possible solutions were analysed to reduce the potential for events associated with these hazards and their consequences. The research team focused mainly on preventive measures. The protection of human health and life was a key priority. It is also important to ensure continuity of exploitation and its economic efficiency, and to reduce the negative impact on the environment, the operation, working conditions, and mining costs. The analysis of the existing hazards and the possible ways of limiting their negative effects should improve work safety and the efficiency of the entire mining industry.

\section{REFERENCES}

SZURGACZ D., 2015. Numerical analysis for an optimization of powered roof support operating in hazard condition of mining tremors, Mining Science Vol. 22, Special Issue 2, s. 171-179.

SZURGACZ D., 2016. Greater dynamic resistance of a hydraulic leg of a powered roof support on the basis of registered rockburst, Interdyscyplinarne zagadnienia w górnictwie i geologii. Tom VI. Str. 77 - 80. DOI: $10.5277 / \mathrm{kdimu} 1600$.

SZURGACZ D., BRODNY J., 2017. Analysis of rock mass dynamic impact influence on the operation of a powered roof support control system. E3S Web of Conferences 29, 00006 (2018) XVIIth Conferences of PhD Students and Young Scientist. https://doi.org/10.1051/e3sconf/20182900006

GIL J., KOŁODZIEJ M., SZURGACZ D., STOIŃSKI K., 2018. Introduction of standardization of powered

\footnotetext{
*Corresponding author: dawidszurgacz@vp.pl
} 


\section{Book of abstracts \\ XX Conference of PhD Students and Young Scientists \\ October 14-16, 2020}

roof supports to increase production efficiency of Polska Grupa Górnicza S.A. Mining - Informatics, Automation and Electrical Engineering, Volume 4 (536) p. 33 - 38.

SZURGACZ D., SOBIK L., BRODNY J., 2019. Ventilation systems in longwall workings with powered longwall complex. Geolinks International Conference on Geosciences. Conference proceedings, Book 1, Volume 1. p. 201 - 209. 26-29 March,Novotel, Athens, Greece 


\title{
UNDERGROUND HARD-COAL MINE AS A HOSTING FACILITY FOR A DATA PROCESSING CENTER INFRASTRUCTURE
}

\author{
K. Varnavskiy ${ }^{1}$, F. Nepsha ${ }^{2 *}$, R. Kostomarov ${ }^{2}$, Q. Chen $^{1}$ \\ ${ }^{1}$ Mechanical and Electronic Engineering Department, Shandong University of Science \\ and Technology, Qingdao, PR China \\ ${ }^{2}$ Power supply of mining and industrial enterprises department, T.F. Gorbachev Kuzbass \\ State Technical University, Kemerovo, the Russian Federation
}

Keywords: Industry - 4.0, coal mines, data processing centers, trigeneration, methane utilization

Despite the global trend towards the abandonment of hydrocarbon fuels in favor of cleaner fuel and energy resources, the coal demand and the development of the coal industry is likely to persist in the coming decades. At the same time, many coal mining enterprises and associated mining towns are in a difficult financial situation caused by the ambiguous dynamics of steam coal prices, including those caused by global events such as the COVID19 pandemic.

In this regard, there is a problem of finding alternative ways to ensure economic sustainability with usage of existing infrastructure of coal mining enterprises. According to the authors of this paper, one of those ways can be the creation of technologies within the framework of the "Coal - Energy - Information" concept. This concept implies the use of infrastructure and production facilities of coal mining enterprises for the construction and provision of engineering infrastructure for data processing centers (DPCs) with the necessary energy resources.

An example of the use of mining infrastructure for DPCs is the Norway's Lefdal mine data center (Forbes insights, 2016). It seems promising to use the Norwegian experience on the territory of the largest coal-mining region of Russia - Kuzbass. The structure of coal mines power supply in terms of the requirements for the reliability of power supply largely equal to DPC.

Considering that most coal mines receive power supply in the first category for power supply reliability (2N), their power supply scheme satisfies level 3 (Tier3). Some mines, with sufficient capacity of autonomous power sources can be equated to level 4 (Tier4).

To improve the reliability of power supply to the data center and coal mine, coal mine methane generation can be used; in this case, the structure of the coal mine's energy supply is as shown in Figure 1.

\footnotetext{
* Corresponding author: nepshafs@ kuzstu.ru
} 


\section{Book of abstracts \\ XX Conference of PhD Students and Young Scientists \\ October 14-16, 2020}

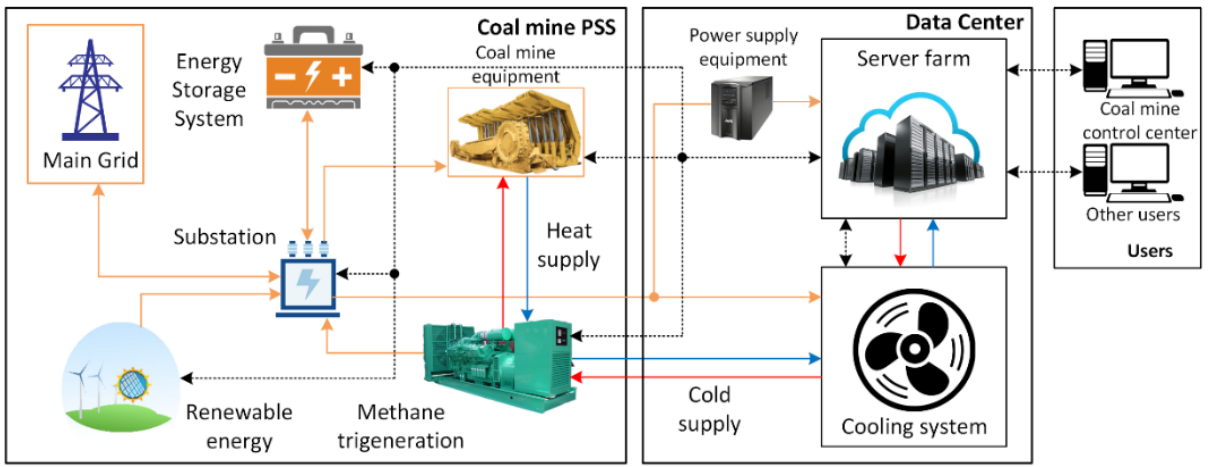

Figure 2 The interactions of DPC, coal mine PSS and main grid

Within the framework of the presented energy supply structure, the processing of coal mine methane (CMM) is assumed to improve energy efficiency (Özgen et al., 2011). For this purpose, it is necessary to use a generating unit operating in a trigeneration cycle - to generate electrical energy to power the equipment of coal mine and data center, and also to provide the mine with heat and server installations with cold.

The authors note a number of technical risks of implementing the proposed structure of energy supply: problems with the CMM supply, malfunctions of power equipment, lack of the necessary electrical load. However, these risks can be eliminated by making optimal decisions at the design stage and organizing timely maintenance by service companies.

In conclusion, it is noted that the proposed concept is extremely expedient for the preservation of city-forming enterprises and requires modeling the energy supply system with a justification for the need to develop trigeneration units operating on CMM.

Acknowledgments. In this paper, the research was sponsored by the Grant of the President of the Russian Federation for the state support of young Russian scientists No. MK-236.2020.8.

\section{REFERENCES}

Forbes insights (2016). Case study: In the Hall of the. Mountain Data King. https://images.forbes.com/forbesinsights/StudyPDFs/IBM-InTheHallOfTheMountainDataKingREPORT.pdf

"TIA-942". TIA-942 Global Registry. Retrieved 28 April 2015.

Karacan, C. Ö., Ruiz, F. A., Cotè, M., \& Phipps, S. (2011). Coal mine methane: A review of capture and utilization practices with benefits to mining safety and to greenhouse gas reduction. In International Journal of Coal Geology. https://doi.org/10.1016/j.coal.2011.02.009 


\title{
LIQUIDATION OF THE EXPLORATION PIT N. 11 FROM THE ROZNA URANIUM DEPOSIT
}

\author{
M. Vokurka ${ }^{1 *}$, O. Molinek ${ }^{1}$ \\ ${ }^{1}$ VSB - Technical University of Ostrava, 70800, Ostrava-Poruba, 17. listopadu, 2172/15, \\ Czech Republic
}

Keywords: backfill, sinking platform, closing mine, uranium, Rozna

The aim of this article is to introduce the history, characteristics and liquidation of one of the first exploratory borings of the Rozna deposit. Based on available characteristics of the main mine workings and the local geology (Vokurka, 2019) a draft of liquidation was created to fulfill the legislative framework of Czech Republic as well as possible (Decree, 1997). The draft was then executed by backfill with unconsolidated rock material (Rankine, 2007) and subsequently by securing the surface pit mouth of the main mine workings by closing sinking platform placed on micropiles (Wojktkowiak, 1999). The finishing works included modifying the surroundings of the exploration pit by land machinery and smoothing the previous mining activity down, so that it doesn't disturb the local morphology.

\section{REFERENCES}

Decree of the Czech Mining Authority No. 52/1997 Coll., Laying Down Requirements to Ensure Occupational Safety and Health and Safety at the Liquidation of Main Mine Workings. In: Collection of Laws of Czech republic, amount 18. 28. 3. 1997.

Rankine, R., Pacheco, M., Sivakugan, N. (2007). Underground Mining with Backfills. Soils and Rocks, vol. 30(2): 93-101.

Vokurka, M. (2019). Liquidation of Uranium Mine Rožná I in Dolní Rožínka. In: Topical Issues of Rational Use of Natural Resources 2019, XV International Forum-Contest of Students and Young Researchers, vol. 2: 759-770. DOI: 10.1201/9781003014638-37

Wojtkowiak, F. Didier, C. (1999). Principles For a Safe Closure of Old Mine Shafts and Adits. In: 9th International Congress on Rock Mechanics, vols 1\&2: 25-30. ISRM-9CONGRESS-1999-005

\footnotetext{
*Corresponding author: michal.vokurka@vsb.cz
} 


\title{
PROCEDURE FOR LAB-SCALE STRENGTH AND FAILURE TESTING OF PHYSICAL MODELS OF FRAME MINE STRUCTURES
}

\author{
N. G. Vysotin ${ }^{1}$, V. I. Leizer ${ }^{1}$, V. A. Eremenko ${ }^{1 *}$, A. M. Yanbekov ${ }^{1}$ \\ ${ }^{1}$ National University of Science and Technology MISIS, Leninsky Av. 4, 119991, Moscow, \\ Russia
}

Keywords: frame mine structure, physical model, stopes, stress-strain behavior, deformation, acoustic emission converter, scalable modular architecture, constantant foil strain gauge, ore recovery.

Operation of any mine, including frame structured mines, alters the stress-strain behavior of enclosing rock mass. The laboratory research requires a plan and a procedure, with description of data acquisition methods (monitoring of strength and deformation characteristics of physical models of the frame mine structure). The implemented laboratory tests used the specially manufactured physical models, a hydraulic pressing machine meant for simulation of strata pressure, as well as a monitoring system including acoustic emission converters and strain gauges. The equipment allows getting an overall picture and enables the stress-strain analysis in a unit block using the theories of similarity and dimensions to understand the influence exerted by the shape, size and arrangement of mined-out stopes on enclosing rock mass stability in case of the frame mine structure.

The authors have developed and presented the test procedure for strength and deformation characteristics of equivalent material models under the influence of shape, size and arrangement of mined-out voids for the frame mine structure and different convergent geotechnologies. The validated equipment for the experimentation includes hydraulic pressing machine P-125, AE converter A-Line DDM-1, scalable modular architecture QMBox; foil strain gauges, and other.

In the uniaxial and triaxial compression tests, the limit stress of the physical models of frame structures was changed in the ranges of 6-5 and 8-20 MPa, respectively.

\footnotetext{
* Corresponding author: prof.eremenko@gmail.com
} 


\title{
DEVELOPMENT OF LOW-COST UNMANNED SURFACE VEHICLE SYSTEM FOR BATHYMETRIC MEASUREMENTS
}

\author{
J. Wajs ${ }^{1 *}$, D. Kasza ${ }^{1}$, B. Skrabanek ${ }^{1}$ \\ ${ }^{1}$ Wrockaw University of Science and Technology, 27 Wyb. Wyspiańskiego St., 50-370 \\ Wroctaw Poland
}

Keywords: unmanned surface vehicle, bathymetric measurements, drones

Unmanned Surface Vehicle (USV) - the subject of this study, is a measurement platform consisting of a boat and a remote and/or autonomous propulsion, navigation, and measurement system. The prototypes of this type of platform, although mainly used for military purposes (Corfield and Young, 2006), come by significant improvements in the 1990s as well as wide range of applications (Manley, 2008). They are used to collect and analyze samples of water, gases, organic matter as well as to map water bodies (Lesser and Mobley, 2007; Naeem et al., 2008; Seto and Crawford, 2015).

The system of the unmanned boat - BATDRON, carrying out bathymetric measurements developed at the Wrocław University of Science and Technology allows for contact-free and quick obtaining of information about the depth. The presented BATDRON project as a low-cost platform enables the sensor to be transported to a specific position, based on the GNSS positioning system of the boat. The applied turbine engines allowed for stable and smooth steering of the boat in RC mode. In the future, the BATDRON platform may be expanded with additional sensors detecting obstacles in order to perform bathymetric missions in an autonomous mode. Depth measurement system - SATLAB SLD 200 single beam echosounder allows to obtain highly accurate coordinates for the underwater numerical terrain modeling.

\section{REFERENCES}

Corfield S.J. and Young, J.M., 2006. Unmanned surface vehicles-game changing technology for naval operations. Ch.15 in Advances in Unmanned Marine Vehicles. Institution of Electrical Engineers, 311-328.

Manley J.E., 2008. Unmanned surface vehicles, 15 years of development. OCEANS 2008, Quebec City, QC, 2008, pp. 1-4, doi: 10.1109/OCEANS.2008.5152052.

Lesser M.P. and Moble, C.D., 2007. Bathymetry, water optical properties, and benthic classification of coral reefs using hyperspectral remote sensing imagery. Coral Reefs 26, 819-829 (2007), https://doi.org/10.1007/s00338-007-0271-5.

Naeem W., Xu, T., Sutton, R., Tiano, A., 2008. The design of a navigation, guidance, and control system for an unmanned surface vehicle for environmental monitoring. Proceedings of the Institution of Mechanical Engineers, Part M: Journal of Engineering for the Maritime Environment, 222(2), 67-79, https://doi.org/10.1243/14750902JEME80.

\footnotetext{
* Corresponding author: jaroslaw.wajs@ @wr.edu.pl
} 


\section{Book of abstracts \\ XX Conference of PhD Students and Young Scientists \\ October 14-16, 2020}

Seto M.L. and Crawford A., 2015. Autonomous shallow water bathymetric measurements for environmental assessment and safe navigation using USVs. OCEANS 2015 - MTS/IEEE Washington, Washington, DC, 2015, pp. 1-5, doi: 10.23919/OCEANS.2015.7404407. 
October 14-16, 2020

\title{
MEASURES TO REDUCE THE ENVIRONMENTAL IMPACT OF THE ŻELAZNY MOST TAILINGS STORAGE FACILITY
}

\author{
S. Zieliński ${ }^{12^{*}}$, P. Stefanek ${ }^{2}$ \\ ${ }^{1}$ KGHM Polska Miedź S.A. Hydrotechnical Unit, Polkowicka 52,59-305 Rudna, Poland \\ ${ }^{2}$ Wrockaw University of Science and Technology, Institute of Geotechnics and \\ Hydrotechnics, Wybrzeże Wyspiańskiego 27, Wroclaw 50-370, Poland
}

Keywords: tailings storage facility, groundwater, dust control, abrasion

The Żelazny Most Tailings Storage Facility, located in south-western Poland, is one of the largest facilities of its kind in the world. Mining wastes from the processing of copper ores have been disposed of continuously for over 40 years. The safe operation of TSF of this size requires the involvement of engineers, specialists and scientists from many fields of science. The article presents the latest experience in activities reducing the environmental impact of the Żelazny Most TSF, including the monitoring of groundwater, air protection and the reliability of pipe infrastructure. KGHM Polish Copper, the TSF operator, has for years been running a system for monitoring the quality of surface and groundwater in the foreground of dams. Very good diagnosis of the hydrogeological conditions in the TSF foundation allowed the research unit to develop a three-dimensional numerical model of groundwater flow. The article also describes the issues related to dust prevention. Active and passive protection methods for the beaches and slopes were presented. Slurries are pumped over a distance of up to $20 \mathrm{~km}$ via multiple pipelines. Due to the high abrasion of the rock material, KGHM runs a pipeline testing and replacement program to ensure the highest level of reliability. The issues presented in the article clearly indicate the attitude of the TSF operator to the reduction of the negative impact of waste storage on the natural environment. This is also confirmed by the presence of many rare species of wild animals in the immediate vicinity, such as fallow deer, beavers and birds of prey.

\footnotetext{
*Corresponding author: szymon.zielinski@kghm.com
} 


\title{
TORSIONAL VIBRATIONS MEASUREMENT TOOLS IN CONDITION MONITORING AND DIAGNOSTICS OF MINING MACHINES
}

\author{
B. Ziętek ${ }^{1 *}$, P. $\operatorname{Krot}^{1}$, P. Borkowski ${ }^{1}$ \\ ${ }^{1}$ Faculty of Geoengineering, Mining and Geology, Wroclaw University of Science and \\ Technology, Na Grobli 15, 50-421 Wroclaw, Poland
}

Keywords: diagnostics, overloading, torque, machine maintenance

Condition monitoring and diagnostics of minerals mining machines is a challenging task for operating companies and their maintenance staff. Conventional approaches based on measurements of vibration, temperature, and other parameters are still not widely implemented in the mining industry due to non-stationary loading conditions. Registration of overloading and resonance modes is not sufficient by the electrical motors current in case of heavy mobile vehicles or stationary mounted mining machines having multi-body structure. Telemetrictorque measurement tools installed in the drivetrains of mining machines allow to account for the variation of loads and give valuable information on damages geared transmissions. This paper represents the different methods of torque measurement and digital telemetry devices under development based on strain gauges. The main focus is on the functionality required for industrial applicability and issues in course of machines operation and maintenance. The additional features, which the torque meters afford for mining machine diagnostics are considered.

\footnotetext{
* Corresponding author: bartlomiej.zietek@pwr.edu.pl
} 


\section{Publisher}

Oficyna Wydawnicza Politechniki Wrocławskiej

\section{ISBN}

978-83-7493-161-8

\section{Conference of PhD Students and Young Scientists}

